\title{
Component Structure of the Penn Inventory for Posttraumatic Stress Disorder (PTSD) Among Veterans Seeking Department of Veterans Affairs Disability Benefits: Concordance by Race/Ethnicity, Gender, Service Era, and Type of Military Exposure
}

\author{
Karen Wahmanholm, MD, MPH ${ }^{1,2}$ \\ Melissa A Polusny, $\mathrm{PhD}^{2,3,4}$ \\ Joseph Westermeyer, MD, PhD, MPH ${ }^{1,2}$ \\ Maureen Murdoch, MD, MPH ${ }^{4,5,6}$
}

${ }^{1}$ Psychiatry Department, Minneapolis VA Health Care System, Minneapolis, MN

${ }^{2}$ Department of Psychiatry, University of MN Medical School, Minneapolis, MN

${ }^{3}$ Mental Health Service, Minneapolis VA Health Care System Minneapolis, MN

${ }^{4}$ Center for Care Delivery and Outcomes Research, Minneapolis, MN

${ }^{5}$ Section of General Internal Medicine, Minneapolis VA Health Care System, Minneapolis, MN

${ }^{6}$ Department of Medicine, University of Minnesota Medical School, Minneapolis, MN

Running Head: Component Structure of the Penn Inventory

Acknowledgements: Funding for this study was provided in part by the Department of Veterans Affairs (VA) Health Services Research and Development (HSR\&D) Service (Gen 97-002). Drs. Polusny and Murdoch are core-investigators for the Center for Care Delivery Outcomes Research at the Minneapolis VA Medical Center, which is a VA Health Services Research and Development (HSR\&D) Service Center of Innovation. 


\begin{abstract}
Background: Although a common neurobiological mechanism for PTSD has been proposed, contextual issues related to race/ethnicity, gender, other sociohistorical factors, and the type of trauma experienced could influence how PTSD presents in any given individual. Objective: To analyze and compare the patterns of correlations (the component structure) of Veterans' responses to the Penn Inventory for PTSD according to their race/ethnicity, gender, service era (e.g., World War II v. Vietnam Conflict), and military trauma exposures (i.e., combat v. sexual assault). Subjects: 3,337 nationally representative Veterans who applied for PTSD disability benefits between 1994 and 1998 and returned a mailed questionnaire between 1998 and 2000. Study Design: Secondary analysis of a cross-sectional survey conducted in 2008. Methods: Using Principal Components analysis, component scores and component comparability coefficients were calculated for each pre-defined subgroup. Results: In the overall sample and across all subgroups, Principal Components analysis consistently identified 2 main latent variables: "alienation and numbing" and "re-experiencing and sleep disturbance." These two components explained $46.3 \%$ of the variance in subjects' responses. For most planned comparisons, the component comparability coefficient met or exceeded 0.80 (all $\mathrm{ps}<$ 0.001), suggesting that the patterns of correlations across subgroups' responses were highly similar. Hispanic Veterans were a notable exception: component comparability coefficients between them and the other race/ethnicity categories ranged from 0.29 to 0.70. Conclusion: Except for Hispanic Veterans, subjects' response patterns to the Penn Inventory for PTSD did not vary substantively by race/ethnicity, gender, trauma exposure, or service era. Implications are discussed.
\end{abstract}

Tags: PTSD, Posttraumatic Stress Disorder, Disability Benefits, Veterans, Measurement, Instrumentation, Scale, Factor Analysis, Component Analysis, Race/Ethnicity Differences, Gender Differences, Sex Differences, Military Sexual Trauma, Sexual Assault, Rape, Combat, World War II, Korean Conflict, Vietnam Conflict, DSM, Review Synthesis 


\section{Introduction}

Although posttraumatic stress disorder (PTSD) affects up to $12 \%$ of United States adults, ${ }^{1-5}$ its lifetime prevalence is considerably higher among combat Veterans. ${ }^{6-11}$ PTSD is the most common psychiatric condition for which Veterans seek Department of Veterans Affairs (VA) disability benefits, and the third most common condition for which they seek VA disability benefits overall. Of the 4.4 million Veterans indemnified by VA for military-related disorders in 2016 , almost $20 \%$ were service connected for PTSD. ${ }^{12}$

Though the original diagnostic criteria for PTSD were largely developed and based on Vietnam combat Veterans' symptoms, ${ }^{13-15}$ PTSD may develop as a result of any horrific trauma, including natural disasters, criminal assault, domestic violence, childhood physical or sexual abuse, and life-threatening illness. ${ }^{16-18}$ Many researchers believe the neurobiological basis of PTSD, such as hyperreactivity of the noradrenergic system ${ }^{19-21}$ and psychophysiological changes, ${ }^{22,23}$ apply universally, regardless of the actual trauma experienced. ${ }^{19,22,24-27}$

Yet, PTSD could manifest differently in some individuals because of ethnocultural or gender differences. ${ }^{26,28-30}$ Sufferers' responses to trauma may vary according to the context and meaning they assign to their experiences -contexts and meanings that could differ by culture, ethnicity, or gender. ${ }^{29,31-36}$ Additionally, different criterion symptoms may be more or less prominent among different populations, ${ }^{30,36-39}$ and somaticallybased symptoms or idioms, may be more prominent in non-Western populations. ${ }^{29,30,37,38}$ In addition to usual DSM criteria, complex forms of PTSD may develop in survivors of prolonged trauma, presenting with somatization, alexithymia and impulse dysregulation, dissociation, sense of self alterations, and relationship disruptions. ${ }^{40,41}$

Comorbid psychiatric conditions and trauma exposures could also vary by gender, socioeconomic class, or ethnic group and affect either vulnerability to PTSD or its symptom presentation. ${ }^{28,33,42}$ For example, Norris ${ }^{2}$ found lower lifetime rates of trauma reported by African Americans or blacks than by whites, but higher trauma effects in black persons. On net, men tend to report more types of trauma than women, ${ }^{5,42,43}$ except for sexual assaults. ${ }^{42}$ Military women have substantially greater odds of both pre-military abuse and in-service sexual assault compared to military men. ${ }^{44-47}$

Military culture itself may affect the contexts and meanings survivors apply to trauma. Compared to civilian sexual assault, for example, military sexual trauma may be particularly damaging ${ }^{48}$ because assault by comrades-in-arms or by superior officers disrupts the interdependency and trust considered essential for individual and troop survival. For service members who file assault charges, events surrounding the investigation could also contribute to PTSD's development. For example, service women filing sexual assault claims have reported being disbelieved, shamed, and retaliated against. ${ }^{49}$ Unlike other employers, the military is simultaneously responsible for victims' treatment and perpetrators' adjudication. Concerns for overall troop safety and military readiness may outweigh individual survivors' therapeutic concerns or needs for justice. ${ }^{50}$ 
However, placing survivors' needs second to the organizations' could compound the former's distress or precipitate distress where none previously existed. Additionally, in the military, survivors' ability to limit future threat, e.g., by quitting or avoiding the perpetrator(s), is often curtailed.

For combat Veterans, the sociohistorical context of war differs across eras and could influence the odds of developing PTSD or how it presents. ${ }^{51,52}$ World War II Veterans experienced higher levels of combat, were more likely to have killed the enemy, and were more likely to have been wounded compared to later war cohorts, ${ }^{53}$ whereas Vietnam Veterans may have witnessed more abusive violence and been "more frequent targets and observers of killing" compared to earlier war Veterans. ${ }^{51}$ Public support for World War II was considerably higher than for the Korean or Vietnam Conflicts, ${ }^{51,52}$ and the high mobilization of all men in the former ensured that World War II servicemen were reasonably representative of all socioeconomic classes. In later conflicts, younger men from the lower socioeconomic strata were overrepresented. While combat severity has consistently been associated with PTSD development; e.g., 3,46,54-59 social support, a welcoming public "homecoming," and higher socioeconomic status may also be protective. ${ }^{57,60-63}$ For many Vietnam Veterans, that Conflict's violence came at a critically important juncture of their lifespan development (i.e., late adolescence, very early adulthood) and could have predisposed them to developing a more complex form of PTSD relative to developmentally older Veterans from earlier wars. ${ }^{41}$

Although there might be theoretical reasons to suppose that PTSD might present differently across race or ethnicity groups, gender, or service era, the few studies examining this question have been equivocal. For example, in a sample of Hispanic community violence victims, Marshall ${ }^{64}$ found a similar latent structure in the PTSD symptoms of English-speakers compared to Spanish-speakers. In a comparison of white Vietnam era Veterans to black and Hispanic Veterans, Ortega and Rosenheck ${ }^{39}$ found black Veterans had lower guilt and higher hyperarousal and avoidance scores; Puerto Rican Hispanic Veterans had higher re-experiencing, hyperarousal, guilt and avoidance scores; and Mexican American Veterans had higher hyperarousal and lower numbing scores. In a study of United States and Mexican hurricane victims, Mexicans reported greater intrusion and avoidance but less arousal, after controlling for trauma severity. ${ }^{37}$ Elhai and colleagues ${ }^{65}$ identified few differences in MMPI-2 responses of male combat Veterans compared to (mostly) female child abuse survivors and, in a confirmatory factor analysis of United States male and female adolescents, the PTSD factor structure appeared equivalent. ${ }^{66}$ In a sample of Somali peacekeepers and Gulf War I Veterans, King and colleagues ${ }^{67}$ identified the same 4 underlying factors for men and women's responses to the PTSD Checklist, ${ }^{68}$ but substantial dissimilarities in factor loadings, factor intercorrelations, and residuals. Hovens and colleagues ${ }^{69}$ identified two additional latent factors, "Concentration Problems" and "Lack of Interest," when they compared Dutch women resistance fighters' responses and men's responses on the Dutch PTSD Scale, but these two factors' importance and stability (one was a couplet) were unclear. In studies comparing Vietnam Conflict Veterans to World War II Veterans, the former have generally been shown to have severer PTSD, ${ }^{51,70-72}$ depression, ${ }^{71}$ global illness severity, ${ }^{71}$ situational adjustment problems, ${ }^{72,73}$ and work impairment, ${ }^{71,73}$ as well as greater 
hostility, ${ }^{71}$ psychoticism, ${ }^{70,71}$ and guilt. ${ }^{51,71}$ Korean Conflict Veterans have been found to have severer PTSD symptoms and greater maladjustment, psychiatric distress, and suicidality when compared to World War II Veterans. ${ }^{51,52}$

This study's goal was to explore these issues further by comparing the component structure of Veterans' responses to a validated instrument of PTSD symptoms according to their race/ethnicity, gender, service era, and military trauma exposure (combat v. sexual trauma). Findings of substantive differences might call into question PTSD's construct validity in some subgroups — or our measure's construct validity — and perhaps suggest fruitful areas for exploring impacts of race/ethnicity, gender, and trauma context on PTSD presentation. Findings of similarity would offer reassuring evidence for the construct validity of PTSD and of our measure.

\section{Methods}

\section{Setting and Subjects}

As described elsewhere, ${ }^{74,75}$ participants were 1,654 men and 1,683 women from an eligible pool of 4,918 nationally representative Veterans who applied for VA disability benefits for PTSD between 1994 and 1998. Veterans were mailed a questionnaire, monetary incentive, and cover letter inviting them to participate in the study. The cover letter included the elements of informed consent (including risks and benefits of participation and the voluntary nature of participation); Veterans' signified their consent to take part in the study by returning a completed survey. The Minneapolis VA Medical Center's Human Studies Subcommittee approved the study's protocol.

Participants returned completed questionnaires between 1998 and 2000. Respondents' mean age was 48 years $(\mathrm{SD}=13)$. Almost a quarter were white and $17 \%$, African American or black. Almost all the men (94\%) and nearly a third of women reported some combat exposure. Almost three quarters of women and $4 \%$ of men reported in-service sexual assault. ${ }^{76}$ About three fifths of the sample's PTSD disability claims were approved. Respondents and non-respondents did not differ significantly in terms of combat injury, combat exposure, or exposure to unwanted sexual attention while in the service. ${ }^{74,75}$ Based on a claims audit of 537 randomly selected Veterans, non-respondents appeared as likely as respondents to have been diagnosed with PTSD by a qualified clinician. ${ }^{77}$ Based on the claims audit, we estimate that $80 \%$ of the sample had a clinical diagnosis of PTSD at the time they filed their disability claim.

\section{Measures}

PTSD symptomatology. Veterans' PTSD symptomatology was measured using the Penn Inventory for Posttraumatic Stress Disorder (Penn Inventory), ${ }^{78}$ a 26-item, selfreport measure of PTSD severity with 0.94 internal consistency and 0.87-0.96 test-retest reliability over a period of 3 to 8 days. Criterion validity was originally established in relation to a structured PTSD clinical protocol. ${ }^{78}$ Scores of 35 or more predict PTSD in Veterans with $93 \%$ to $97 \%$ accuracy. ${ }^{44,79}$ Although originally developed in Vietnam 
combat Veterans, the Penn Inventory has also been validated in general psychiatric patients and civilian disaster survivors. ${ }^{78}$ Importantly, it measures PTSD independently of the inciting trauma ${ }^{80}$ making it an ideal test of PTSD responses in populations with heterogeneous trauma exposures. Further, African Americans were well represented in the development samples, ${ }^{78,81}$ and it was been shown to have similar psychometric properties among women and men. ${ }^{82}$

Race/ethnicity. Respondents self-identified their race/ethnicity by selecting from 6 survey categories, checking as many as applied. The categories were: 1) American Indian or Alaskan Native, 2) Asian, 3) Black or African American, 4) Hispanic or Latino, 5) Native Hawaiian or Other Pacific Islander, and 6) White. We compared the Penn Inventory component structure for Veterans who self-identified as white, black, American Indian, or Hispanic. Too few subjects self-identified as Asian or Hawaiian/Pacific Islander to do separate factor analyses on those groups.

Military trauma exposures. Veterans' combat exposure status was measured using a modified, 22-item version of the Combat Exposure Index (CEI). ${ }^{83}$ Scores $\geq 1$ indicated combat exposure. Three items from the criminal sexual misconduct subscale of the Sexual Harassment Inventory $(\mathrm{SHI})^{84}$ plus a fourth question asking about other in-service sexual experiences determined Veterans' in-service sexual assault status.

Service era. Veterans' service era was abstracted from the Veterans Benefits Administration's (VBA) Veterans Issues Tracking Adjudication Log (VITAL). We compared the Penn Inventory response patterns of Veterans who served in World War II, the Korean Conflict, the Vietnam Conflict, post-Vietnam Conflict, the Gulf War I, and post-Gulf War I. Veterans who served in more than one conflict $(n=57)$ were assigned to the most recent conflict. Veterans categorized as serving in the Korean Conflict included 2 Veterans who had served just prior to that conflict and 52 Veterans who had served just after it.

\section{Analysis}

Although the Penn Inventory's internal consistency, test-retest reliability and criterion validity have been substantiated, there has been no published factor analysis of subjects' test responses. Consequently, we used exploratory factor analysis to estimate the scale's factor structure. While ideally a comparison of the factor structure across subgroups would employ confirmatory factor analysis, we believed that "confirming" a scale's factor structure in the same population from which it was initially derived would substantially increase our Type I error. Thus, we used Nunnally's ${ }^{85}$, pg. 433 technique for comparing factor scores and responses' patterns of correlations across different persons using exploratory factor techniques.

First, we conducted a separate factor analysis on the Penn Inventory responses for each subgroup of interest and calculated factors scores for each individual in that subgroup as usual. We then took each subgroups' factor loadings, using them as weights, and applied them to the other subgroups' responses. Thus, for each individual, we created 
13 sets of factor scores corresponding to the "male" weights, the "female" weights, and so on. All factor scores were computed using the regression method. The resulting factor scores were then correlated using Pearson's product-moment correlation coefficient. This correlation is known as the comparability correlation coefficient. Per Everett, ${ }^{86}$ a comparability correlation coefficient of 0.90 or more indicates that the different factor versions are essentially the same, and coefficients of 0.80 or more indicate that they are "very similar."

For all analyses, we used Principal Component extraction. In component analysis, factors are the linear combinations of actual variables, and factor scores for individual respondents can be perfectly determined; ${ }^{85}$, pg. 424 consequently, whether or how we rotated the factors was relatively unimportant to the study's goals. However, using a known factor structure, Everett ${ }^{86}$ has shown that Varimax rotation is preferable to no rotation or to oblique rotation when computing factor comparability coefficients (assuming $\geq 0.50$ correlation between factors). When the correlation between factors is less than 0.30, Varimax rotation is essentially equivalent to oblique methods. Thus, although data suggest that PTSD symptom clusters are conceptually correlated to one another, we used the Varimax procedure to rotate factors. We determined the number of factors to extract by inspecting the Scree plot. ${ }^{87}$ Because membership in more than one group (e.g., some Veterans reported both combat exposure and military sexual assault) could have spuriously inflated the apparent concordance of response patterns of correlations within affected subgroups, we conducted a second set of analyses in which all such Veterans were excluded. Analyses were conducted in 2008 using SPSS for Windows, release 11 .

\section{Results}

The Kaiser-Meyer-Olkin (KMO) measure of sampling adequacy of the entire sample was 0.97 and Bartlett's Test of Sphericity was significant at a p-value of $<0.0001$. In the subgroups the KMO sampling adequacy ranged from 0.84 to 0.97 . In all subgroups the p-value for Bartlett's Test of Sphericity was $<0.0001$.

\section{Scree plot}

As Figure 1 shows, there was a sharp elbow at the second component, suggesting the scale had just two meaningful components. We found the same sharp elbow at the second component for each of the pre-defined Veteran subgroups (data not shown)

\section{Results of Component Analysis}

Table 1 shows the Penn Inventory's component structure for the entire sample. As can be seen from the Table, few items loaded uniquely on just one component, suggesting that most items tapped into both the scale's underlying latent variables. That said, the first component appeared to be comprised of items predominantly related to alienation and to lack of direction. Many of these items are similar to the numbing and decreased

responsiveness symptoms listed in Criterion C of DSM-IV diagnostic criteria for PTSD. ${ }^{8}$ 
Component 1 also included Criterion D hyperarousal symptoms related to anger and concentration. The second component was predominantly composed of re-experiencing symptoms, classic to Criterion B, plus sleep disturbance items that are generally categorized as hyperarousal symptoms in Criterion D. We named Component 1, "Alienation and Numbing," and Component 2, "Re-Experiencing and Sleep Disturbance."

\section{Correlation of Subgroup Component Scores}

As can be seen in Tables 2 through 5, the comparability correlation coefficients across planned subgroup comparisons generally met or exceeded 0.80 , suggesting that the response pattern correlations in these subgroups were either very similar or substantially the same. Even unplanned comparisons, e.g., between women and combat-exposed Veterans, generally showed comparability correlation coefficients exceeding 0.80 .

The one notable exception was the finding of relatively low Component 1 comparability correlation coefficients between self-identified Hispanic Veterans and Veterans selecting other race/ethnicity categories. Component 2 comparability correlation coefficients between Hispanic Veterans and Veterans selecting the other race/ethnicity categories were especially low. The component structure of Hispanic Veterans' responses showed that most items related to sleep difficulties loaded with alienation items and explained $41.5 \%$ of the variance in these Veterans' responses, whereas the second component, explaining $5.9 \%$ of the variance, was related to items assessing numbing, hyperarousal, and re-experiencing trauma. Compared to other Veterans, self-identified Hispanic Veterans were more likely to be male (56.4\% v. 49.2\%), and they reported severer combat exposure and PTSD symptomatology and fewer military sexual assaults (data not shown). Yet their component comparability correlation coefficients were especially low when compared to men and to combat-exposed Veterans.

Results did not change importantly when the analyses were repeated to exclude subjects with membership in multiple subgroups (data not shown).

\section{Discussion}

Few studies have compared the factor or component structure of PTSD symptoms across sociodemographic groups or across differing traumatic experiences. Although the Penn Inventory was developed based on Vietnam Veterans' symptoms, our exploratory analyses indicated consistency in the Penn Inventory's response patterns of correlations across gender, most race/ethnicity categories, trauma type, and service era. In the overall sample and across most subgroups, we identified two major components of PTSD symptomatology: 1) "Alienation and Numbing," and 2) "Re-experiencing and Sleep Disturbance".

Table 6 summarizes most of the extant literature on the latent structure of PTSD up until 2008. As Table 6 shows, relatively little consistency has been found in the number and types of factors extracted from diverse samples using different PTSD measures. 
Further, inconsistent or overly broad factor labels may have masked additional discrepancies across studies. ${ }^{\text {cf, }}{ }^{89}$ For example, in one study, sleep disturbances loaded on a factor named "Intrusions;" increased irritability loaded on a factor named "Numbing."16 In other studies, these symptoms loaded together on a factor named "Hyperarousal," whereas other symptoms of hyperarousal (e.g., exaggerated startle) loaded on a factor named "Intrusions and Avoidance." "90,91 Items labeled as "Avoidance" on the Purdue Post-Traumatic Stress Scale ${ }^{92}$ included "felt guilty about surviving or about what [I] had to do to survive during the war" and "lost interest in one or more of [my] activities (e.g., work, hobbies, etc.)," whereas an item one might consider prototypical of avoidance, "To what extent have you avoided activities that reminded you of the war?," loaded almost equally on the "Arousal" and "Avoidance" factors. ${ }^{93}$

As Simms and colleagues ${ }^{89}$ note, it is exceptionally difficult to compare factor structures across studies because samples, methods, and measures differ. Criteria for PTSD have also changed over the years, offering another difficulty. Studies performed in the 1980's using DSM-III e.g., 94-96 did not emphasize avoidance symptoms. The three symptom criteria (Criteria B, C \& D) for DSM-III were, respectively, 1) re-experiencing; 2) "numbing of responsiveness to or reduced involvement with the external world;" and 3) a miscellaneous category that included hyperalertness, sleep disturbance, avoidance, memory or concentration problems and guilt. Since then avoidance symptoms have taken an increasingly more important role in diagnostic criteria for PTSD. In DSM-III-R, avoidance joined numbing in Criterion C ("Persistent avoidance of stimuli associated with the trauma or numbing of general responsiveness"), and, in DSM-IV, it became essential to meeting Criterion C ("Persistent avoidance of stimuli associated with the trauma and numbing of general responsiveness").

The Penn Inventory was constructed using DSM-III-R criteria, and, though it contains items from each of the 3 symptom criteria needed for diagnosis of PTSD in DSM-IV, there are no items that specifically assess avoidance. This could explain why a evaluation of the Penn Inventory in 80 traumatized British citizens demonstrated somewhat lower specificity than had previously been reported for it. ${ }^{82}$ Because avoidance was not directly assessed in our sample, we do not know if it varied across our subgroups.

While PTSD's precise factor structure is uncertain, most data available up until 2005 supported a hierarchical structure. That is, lower order factors - whatever their name and number, loaded onto a higher order, "PTSD," factor. ${ }^{13,37,90,91,97-104}$ While there are exceptions, e.g., 64,80,102,105,106 even they could be consistent with a hierarchical model. ${ }^{64,80,102,106,107}$ Our own findings of a very large first component (recognizing that our techniques were geared toward such a finding), substantial loadings on both components for many items, and positive loadings on both components for most items are also consistent with a higher order "PTSD" factor. Increasingly, investigators have suggested that PTSD be considered a "continuum of disturbance severity" 13 , pg. 332 rather than a categorical disorder that is present or absent. ${ }^{13,63,90,100,103,108-111}$ High correlations between avoidance symptoms and either intrusive or arousal symptoms in previous work $^{112,113}$ suggest that failure to assess avoidance does not necessarily doom a test's usefulness in ranking individuals according to their PTSD symptom severity. Indeed, 
based on taxometric analyses that strongly supported PTSD's dimensional latent structure, Ruscio, Ruscio \& Keane ${ }^{108}$ have suggested that "assessment instruments designed to differentiate individuals with and without PTSD may be less useful and less powerful than those that measure the severity with which PTSD symptoms are experienced."

The Penn Inventory has a number of highly desirable characteristics for a self-report measure, including a good correspondence between symptom severity and trauma severity, ${ }^{77,78}$ convergent validity with other PTSD measures, ${ }^{78,114,115}$ clinically relevant benchmarks, ${ }^{78,81,116}$ sensitivity to treatment effects, ${ }^{78,81,116,117}$ and the ability to measure PTSD symptoms regardless of the inciting trauma. ${ }^{78}$ Normative values are available for Veteran and non-Veteran clinical populations ${ }^{78,82,115,118}$ and for non-clinical populations. ${ }^{78}$ To these we now add data suggesting similar psychometric properties across several race/ethnicity groups, gender, service era, and two types of trauma.

Among our Hispanic Veterans, symptoms of alienation and sleep problems explained more variance in their responses than did symptoms related to numbing, re-experiencing, or hyperarousal. Using the PTSD Checklist-Civilian ${ }^{119}$ version in Spanish- and Englishspeaking trauma victims, Orlando and Marshall ${ }^{120}$ also identified non-equivalence across distressing dreams, avoidance of trauma reminders, and hypervigilance. ${ }^{119}$ However, their data did not suggest that these items held greater salience for one group compared to the other. Though PTSD's construct validity has generally been supported in Hispanic samples, ${ }^{37,39}$ Jenkins $^{30}$ has questioned the cultural validity of some Criterion $\mathrm{C}$ symptoms in Salvadoran women refugees.

The Penn Inventory's emphasis on spirituality and alienation is relatively unique among PTSD measures and may be particularly salient for Hispanic persons. ${ }^{39,121,122}$ In a qualitative assessment of post-trauma effects in 24 Mexican disaster survivors, depression and family concerns clustered together and were distinct from more usual DSM criteria for PTSD. ${ }^{123}$ In a sample of 63 Hispanic Veterans, those with PTSD were significantly more likely to negatively rate their social relationships compared to mentally healthy controls, and they reported weaker linkages to their cultural heritage as well. ${ }^{121}$ In a much larger, nationally representative sample of Veterans in treatment for PTSD, Puerto Rican Hispanics were significantly more likely to need assistance with interpersonal relationships than white or African American or black Veterans. Thus, the Penn Inventory's low component comparability coefficients for Hispanic Veterans relative to other subgroups in this study may reflect a cultural phenomenon whereby Hispanic Veterans manifest PTSD symptoms somewhat differently than others. ${ }^{124}$

This study was limited to Veterans who applied for PTSD disability benefits. Results may not be generalizable to other populations with PTSD symptoms. Confirmatory factor analysis was not suitable for this initial analysis, but in the future would offer a more rigorous test of subgroups' factor structure similarities and differences. Among Hispanic individuals, heterogeneous PTSD response patterns by country of origin have been identified. ${ }^{39,64}$ Our Hispanic subgroup's relatively small size plus the potential for such within-group heterogeneity could have resulted in factorial instability. We recommend 
replicating our work in larger samples where Hispanic subgroups might be identified and analyzed separately. Developing and incorporating an "avoidance" item into the Penn Inventory might increase its relevancy to current PTSD theories. It would be interesting to see how adding such an item might influence the Penn Inventory's factor structure.

For the most part, our results were promising and supported excellent stability in the Penn Inventory's factor structure across gender, service era, military trauma exposures, and service era. The Penn Inventory's performance in Hispanic Veterans should be explored more deeply. Despite the low component comparability coefficients recorded for Hispanic Veterans, the Penn Inventory might actually be a measure of choice for PTSD in this population because it taps into items that may be particularly relevant to them. Head-to-head comparisons with other PTSD measures might help elucidate these issues. 


\section{References}

1. Breslau N, Davis G, Andreski P, Peterson E. Traumatic events and posttraumatic stress disorder in an urban population of young adults. Arch Gen Psychiatry. 1991;48(March):216-222.

2. Norris F. Epidemiology of trauma: Frequency and impact of different potentially traumatic events on different demographic groups. J Consult Clin Psychol. 1992;60(3):409-418.

3. Kessler R, Sonnega A, Bromet E, Hughes M, Nelson C. Posttraumatic stress disorder in the National Comorbidity Survey. Arch Gen Psychiatry. 1995;52:1048-1060.

4. Resnick H, Kilpatrick D, Dansky B, Saunders B, Best C. Prevalence of civilian trauma and posttraumatic stress disorder in a representative national sample of women. J Consult Clin Psychol. 1993;61:984-991.

5. Breslau N, Kessler R, Chilcoat H, Schultz L, Davis G, Andreski P. Trauma and posttraumatic stress disorder in the community: The 1996 Detroit Area Survey of Trauma. Arch Gen Psychiatry. 1998;55(7):626-632.

6. Egendorf A, Kadushin C, Laufer R, Rothbart G, Sloan L. Legacies of Vietnam. Comparative adjustment of veterans and their peers. Washington, DC: Government Printing Office; 1981.

7. Kulka R, Schlenger W, Fairbank J, et al. Contractual report of findings from the National Vietnam Veterans Readjustment Study. Vol II: Tables of findings. Research Triangle Park, NC: Research Triangle Institute; 1988.

8. Kulka R, Schlenger W, Fairbank J, et al. Contractual report of findings from the National Vietnam Veterans Readjustment Study. Vol. 1: Executive summary, description of findings, and technical appendices. Research Triangle Park, NC: Research Triangle Institute; 1988.

9. Blank Jr. A. The longitudinal course of posttraumatic stress disorder. In: Davidson J, Foa E, eds. Posttraumatic stress disorder: DSM-IV and beyond. Washington, DC: American Psychiatric Press; 1993:3-21.

10. Sutker P, Allain A, Winstead D. Psychopathology and psychiatric diagnoses of World War II Pacific Theater prisoner of war survivors and combat veterans. Am J Psychiatry. 1993;150:240.

11. Engdahl B, Dikel TN, Eberly R, Blank A, Jr. Posttraumatic stress disorder in a community group of former prisoners of war: a normative response to severe trauma. Am J Psychiatry. 1997;154(11):1576-1581.

12. Veterans Benefits Administration. Annual Benefits Report: Fiscal Year 2016: Compensation. Washington DC: US Department of Veterans Affairs; 2016.

13. Anthony J, Lonigan C, Hecht S. Dimensionality of posttraumatic stress disorder symptoms in children exposed to disaster: Results from confirmatory factor analyses. J Abnorm Psychol. 1999;108(2):326-336.

14. McNally R. Progress and controversy in the study of posttraumatic stress disorder. Annu Rev Psychol. 2003;54:229-252.

15. Cloitre M, Koene K, Gratz K, Jakupcak M. Differential diagnosis of PTSD in women. In: Kimerling R, Ouimette P, Wolfe J, eds. Gender and PTSD. New York: Guilford Press; 2002:117-149. 
16. Foa E, Riggs D, Gershuny B. Arousal, numbing, and intrusion: Symptom structure of PTSD following assault. Am J Psychiatry. 1995;152(1):116-120.

17. Green B, Rowland J, Krupnick J, et al. Prevalence of posttraumatic stress disorder in women with breast cancer. Psychosomatics. 1998;39:102-111.

18. Goenjian AK, Steinberg AM, Najarian LM, Fairbanks LA, Tashjian M, Pynoos RS. Prospective study of posttraumatic stress, anxiety and depressive reactions after earthquake and political violence. American Journal of Psychiatry. 2000;157(6):911-916.

19. Peirce J, Newton T, Buckley T, Keane T. Gender and psychophysiology of PTSD. In: Kimerling R, Ouimette P, Wolfe J, eds. Gender and PTSD. New York: Guilford Press; 2002:177-204.

20. Southwick S, Bremner J, Rasmusson A, Morgan C, Arnsten A, Charney D. Role of norephinephrine in the pathophysiology and treatment of posttraumatic stress disorder. Biol Psychiatry. 1999;46(9):1192-1204.

21. Grossman R, Buchsbaum M, Yehuda R. Neuroimaging studies in post-traumatic stress disorder. Psychiatr Clin North Am. 2002;25:317-340.

22. Gurvits T, Gilbertson M, Lasko N, et al. Neurologic soft signs in chronic posttraumatic stress disorder. Arch Gen Psychiatry. 2000;57:181-186.

23. Orr SP, Metzger LJ, Pitman RK. Psychophysiology of post-traumatic stress disorder. Psychiatr Clin North Am. 2002;25:271-293.

24. Brewin C, Dalgeish T, Joseph S. A dual representation theory of posttraumatic stress disorder. Psychol Rev. 1996;103(4):670-686.

25. McNally R. Experimental approaches to cognitive abnormality in posttraumatic stress disorder. Clin Psychol Rev. 1998;18(8):971-982.

26. Marsella A, Friedman M, Spain E. Ethnocultural aspects of posttraumatic stress disorder. In: Oldham J, Riba M, Tasman A, eds. Review of Psychiatry. Vol 12. Washington DC: American Psychiatric Press; 1993:157-181.

27. Sack W, Seeley J, Clarke G. Does PTSD transcend cultural barriers? A study from the Khmer Adolescent Refugee Project. J Am Acad Child Adolesc Psychiatry. 1997;36(1):49-54.

28. Yehuda R. Biological factors associated with susceptibility to posttraumatic stress disorder. Can J Psychiatry. 1999;44(Feb):34-39.

29. Kirmayer L. Confusion of the senses: Implications of ethnocultural variations in somatoform and dissociative disorders for PTSD. In: Marsella A, Friedman M, Gerrity E, Scurfield R, eds. Ethnocultural Aspects of Posttraumatic Stress Disorder. Washington, DC: American Psychological Association; 1996:131-163.

30. Jenkins J. Culture, emotion, and PTSD. In: Marsella A, Friedman M, Gerrity E, Scurfield R, eds. Ethnocultural Aspects of Posttraumatic Stress Disorder. Washington, DC: American Psychological Association; 1996:165-182.

31. Carlier I, Lamberts R, Gersons B. The dimensionality of trauma: A multidimensional scaling comparison of police officers with and without posttraumatic stress disorder. Psychiatry Res. 2000;97:29-39.

32. Manson S, Beals J, O'Nell T, et al. Wounded spirits, ailing hearts: PTSD and related disorders among American Indians. In: Marsella A, Friedman M, Gerrity E, Scurfield R, eds. Ethnocultural Aspects of Posttraumatic Stress Disorder. Washington, DC: American Psychological Association; 1996:255-284. 
33. Kimerling R, Ouimette P, Wolfe J, eds. Gender and PTSD. New York: Guilford Press; 2002.

34. Wolfe J, Kimerling R. Gender issues in the assessment of posttraumatic stress disorder. In: Wilson J, Keane T, eds. Assessing Psychological Trauma and PTSD. 1st ed. New York: Guilford Press; 1997:192-238.

35. Baker A, Shaloub-Kevorkian N. Effects of political and military traumas on children: The Palestinian case. Clin Psychol Rev. 1999;19(8):935-950.

36. de Jong J, Komproe I, Van Ommeren M, et al. Lifetime events and posttraumatic stress disorder in 4 postconflict settings. JAMA. 2001;286(5):555-562.

37. Norris F, Perilla J, Murphy A. Postdisaster stress in the United States and Mexico: A cross-cultural test of the multicriterion conceptual model of posttraumatic stress disorder. J Abnorm Psychol. 2001;110(4):553-563.

38. Terheggen MA, Stroebe MS, Kleber RJ. Western conceptualizations and Eastern experience: A cross-cultural study of traumatic stress reactions among Tibetan refugees in India. J Trauma Stress. 2001;14(2):391-403.

39. Ortega A, Rosenheck R. Posttraumatic stress disorder among Hispanic Vietnam veterans. Am J Psychiatry. 2000;157(4):615-619.

40. Herman J. Sequelae of prolonged and repeated trauma: Evidence for a complex posttraumatic syndrome (DESNOS). In: Davidson J, Foa E, eds. Post-traumatic Stress Disorder: DSM-IV and Beyond. Washington, DC: American Psychiatric Press; 1993:213-228.

41. Ford J. Disorders of extreme stress following war-zone military trauma: Associated features of PTSD or comorbid but distinct syndromes? J Consult Clin Psychol. 1999;67(1):3-12.

42. Norris F, Foster J, Weisshaar D. The epidemiology of sex differences in PTSD across developmental, societal and research contexts. In: Kimerling R, Ouimette P, Wolfe J, eds. Gender and PTSD. Vol 3-42. New York: Guilford Press; 2002.

43. Vrana S, Lauterbach D. Prevalence of traumatic events and post-traumatic psychological symptoms in a nonclinical sample of college students. J Trauma Stress. 1994;7(2):289-302.

44. Baker D, Boat B, Grinvalsky H, Geracioti Jr. T. Interpersonal trauma and animalrelated experiences in female and male military veterans: Implications for program development. Milit Med. 1998;163(Jan):20-25.

45. Merrill L, Newell C, Milner J, et al. Prevalence of premilitary adult sexual victimization and aggression in a Navy recruit sample. Milit Med. 1998;163(Apr):209-212.

46. Engel Jr. C, Engel A, Campbell S, McFall M, Russo J, Katon W. Posttraumatic stress disorder symptoms and precombat sexual and physical abuse in Desert Storm veterans. J Nerv Ment Dis. 1993;181(11):683-688.

47. Stretch R, Knudson K, Durand D. Effects of premilitary and military trauma on the development of post-traumatic stress disorder symptoms in female and male active duty soldiers. Milit Med. 1998;163(7):466-470.

48. Fontana A, Rosenheck R. Duty-related and sexual stress in the etiology of PTSD among women veterans who seek treatment. Psychiatr Serv. 1998;49(5):658-662. 
49. Bastian L, Lancaster A, Reyst H. Department of Defense 1995 Sexual Harassment Survey (Report No. 96-014). Arlington, VA: Defense Manpower Data Center; 1996.

50. Furey J. Women Veterans Issues, Part 1: Developing PTSD Sexual Assault Claims in: C\&P Training Operations Teleconference [ video broadcast]. Dec. 17, 1996.

51. Fontana A, Rosenheck R. Traumatic war stressors and psychiatric symptoms among World War II, Korean, and Vietnam War veterans. Psychol Aging. 1994;9(1):27-33.

52. McCranie E, Hyer L. Posttraumatic stress disorder symptoms in Korean Conflict and World War II combat veterans seeking outpatient treatment. J Trauma Stress. 2000;13(3):427-439.

53. Spiro A, Schnurr P, Aldwin C. Combat-related posttraumatic stress disorder symptoms in older men. Psychol Aging. 1994;9(1):17-26.

54. Foy D, Sipprelle R, Rueger D, Carroll E. Etiology of posttraumatic stress disorder in Vietnam veterans: analysis of premilitary, military, and combat exposure influences. J Consult Clin Psychol. 1984;52(1):79-87.

55. Ullman S, Siegel J. Predictors of exposure to traumatic events and posttraumatic stress sequelae. J Community Psychol. 1994;22(October):328-338.

56. Boscarino J. Post-traumatic stress and associated disorders among Vietnam veterans: The significance of combat exposure and social support. J Trauma Stress. 1995;8(2):317-337.

57. Johnson D, Lubin H, Rosenheck R, Fontana A, Southwick S, Charney D. The impact of the homecoming reception on the development of posttraumatic stress disorder: The West Haven Homecoming Stress Scale (WHHSS). J Trauma Stress. 1997;10(2):259-277.

58. Wolfe J, Sharkansky E, Read J, Dawson R, Martin J, Ouimette P. Sexual harassment and assault as predictors of PTSD symptomatology among US female Persian Gulf War military personnel. J Interpers Violence. 1998;13(1):40-57.

59. Hoge C, Castro C, Messer S, McGurk D, Cotting D, Koffman R. Combat duty in Iraq and Afghanistan, mental health problems, and barriers to care. New Engl J Med. 2004;351(1):13-22.

60. King L, King D, Fairbank J, Keane T, Adams G. Resilience-recovery factors in post-traumatic stress disorder among female and male Vietnam veterans: Hardiness, postwar social support, and additional stressful life events. J Pers Soc Psychol. 1998;74(2):420-434.

61. King D, King L, Foy D, Keane T, Fairbank J. Posttraumatic stress disorder in a national sample of female and male Vietnam veterans: Risk factors, War-zone stressors, and resilience-recovery variables. J Abnorm Psychol. 1999;108(1):164170.

62. Fontana A, Schwartz L, Rosenheck R. Posttraumatic stress disorder among female Vietnam veterans: A causal model of etiology. Am J Public Health. 1997;87(2):169-175.

63. Kulka R, Schlenger W, Fairbank J, et al. Trauma and the Vietnam War generation. New York: Brunner/Mazel; 1990. 
64. Marshall G. Posttraumatic Stress Disorder Symptom Checklist: Factor structure and English-Spanish measurement invariance. J Trauma Stress. 2004;17(3):223230.

65. Elhai J, Frueh B, Gold P, Gold S, Hamner M. Clinical presentation of posttraumatic stress disorder across trauma populations: A comparison of MMPI2 profiles of combat veterans and adult survivors of child sexual abuse. $J$ Nerv Ment Dis. 2000;188:708-713.

66. Foy D, Wood J, King D, King L, Resnick H. Los Angeles Symptom Checklist: Psychometric evidence with an adolescent sample. Assessment. 1997;4(4):377384.

67. King D, King L, Weathers F, Litz B, Herman D. Confirmatory factor analysis of the PTSD Checklist. Paper presented at: American Psychological Association 1997; Chicago, IL.

68. Weathers F, Litz B, Herman D, Huska J, Keane T. The PTSD Checklist (PCL): Reliability, validity and diagnostic utility. Paper presented at: International Society of Traumatic Stress Studies1993; San Antonio, TX.

69. Hovens J, Falger P, Op de Velde W, Meijer P, de Groen J, van Dun H. A selfrating scale for the assessment of posttraumatic stress disorder in Dutch resitance veterans of World War II. J Clin Psychol. 1993;49(2):196-203.

70. Blake D, Keane T, Wine P, Mora C, Taylor K, Lyons J. Prevalence of PTSD symptoms in combat veterans seeking medical treatment. J Trauma Stress. 1990;3(1):15-27.

71. Davidson JRT, Kudler H, Saunders W, Smith R. Symptom and comorbidity patterns in World War II and Vietnam veterans with posttraumatic stress disorder. Compr Psychiatr. 1990;31(2):162-170.

72. Blum M, Kelly E, Meyer M, Carlson C, Hodson W. An assessment of the treatment needs of Vietnam-era veterans. Hosp Commun Psychiatr. 1984;35(7):691-696.

73. Rosenheck R, Fontana A. Long-term sequelae of combat in World War II, Korea, and Vietnam: A comparative study. In: Ursano R, McCaughey B, Fullerton C, eds. Individual and community responses to trauma and disaster: The structure of human chaos. Vol xvi. New York: Cambridge University Press; 1994:330-359.

74. Murdoch M, Hodges J, Hunt C, Cowper D, Kressin N, O'Brien N. Gender differences in service connection for PTSD. Med Care. 2003;41(8):950-961.

75. Murdoch M, Hodges J, Cowper D, Fortier L, van Ryn M. Racial disparities in VA service connection for posttraumatic stress disorder disability. Med Care. 2003;41(4):536-549.

76. Murdoch M, Polusny M, Hodges J, O'Brien N. Prevalence of in-service and postservice sexual assault among combat and noncombat veterans applying for Department of Veterans Affairs posttraumatic stress disorder disability benefits. Milit Med. 2004;169(May):392-395.

77. Murdoch M, Polusny M, Hodges J, Cowper D. The association between inservice sexual harassment and posttraumatic stress disorder among compensationseeking veterans. Milit Med. 2006;171(2):166-173.

78. Hammarberg M. Penn Inventory for Posttraumatic Stress Disorder: psychometric properties. Psychol Assess. 1992;4(1):67-76. 
79. Hammarberg M. Scoring the Penn Inventory for PTSD. Philadelphia: University of Pennsylvania; 1990.

80. Vreven D, Gudanowski D, King L, King D. The civilian version of the Mississippi PTSD Scale: a psychometric evaluation. J Trauma Stress. 1995;8(1):91-109.

81. Hammarberg M, Silver S. Outcome of treatment for posttraumatic stress disorder in a primary care unit serving Vietnam veterans. J Trauma Stress. 1994;7(2):195216.

82. Scragg P, Grey N, Lee D, Young K, Turner S. A brief report on the Penn Inventory for Posttraumatic Stress Disorder. J Trauma Stress. 2001;14(3):605611.

83. Janes G, Goldberg J, Eisen S, True W. Reliability and validity of a combat exposure index for Vietnam veterans. J Clin Psychol. 1991;47:80-86.

84. Murdoch M, McGovern P. Development and validation of the Sexual Harassment Inventory. Violence Vict. 1998;13(3):203-216.

85. Nunnally J. Psychometric theory. 2nd ed. New York: McGraw-Hill; 1978.

86. Everett J. Factor comparability as a means of determining the number of factors and their rotation. Multivariate Behav Res. 1983;18:197-218.

87. Cattell R. The scree test for the number of factors. Multivariate Behav Res Ther. 1966;1:245.

88. Autor D, Duggan M. The growth in the Social Security Disability rolls: A fiscal crisis unfolding Journal of Economic Perspectives. 2006;20(3):71-96.

89. Simms L, Watson D, Doebbeling B. Confirmatory factor analyses of posttraumatic stress symptoms in deployed and non-deployed veterans of the Gulf War. J Abnorm Psychol. 2002;111(4):637-647.

90. Buckley T, Blanchard E, Hickling E. A confirmatory factor analysis of posttraumatic stress symptoms. Behav Res Ther. 1998;36(11):1091-1099.

91. Taylor S, Kuch K, Koch W, Crockett D, Passey G. The structure of posttraumatic stress symptoms. J Abnorm Psychol. 1998;107(1):154-160.

92. Figley C. Helping Traumatized Families. San Francisco: Jossy-Bass; 1989.

93. Hendrix C, Anelli L, Gibbs J, Fournier D. Validation of the Purdue PostTraumatic Stress Scale on a sample of Vietnam veterans. J Trauma Stress. 1994;7(2):311-319.

94. Silver S, Iacono C. Factor-analytic support for DSM-III's post-traumatic stress disorder for Vietnam veterans. J Clin Psychol. 1984;40(1):5-14.

95. Wilson J, Krauss G. Predicting post-traumatic stress disorders among Vietnam veterans. In: Kelly W, ed. Post-traumatic stress disorder and the war veteran patient. New York: Brunner-Mazel; 1985.

96. Keane T, Gerardi R, Lyons J, Wolfe J. The interrelationship of substance abuse and posttraumatic stress disorder. In: Galanter M, ed. Recent developments in alcoholism. Vol 6. New York: Plenum Press; 1988:27-48.

97. King L, King D. Latent structure of the Mississippi Scale for Combat-Related Post-Traumatic Stress Disorder: Exploratory and higher order confirmatory factor analysis. Assessment. 1994;1(3):275-291.

98. Engdahl B, Eberly R, Blake J. Assessment of posttraumatic stress disorder in World War II veterans. Psychol Assess. 1996;8(4):445-449. 
99. Davidson J, Book S, Colket J, et al. Assessment of a new self-rating scale for posttraumatic stress disorder. Psychol Med. 1997;27:153-160.

100. Maes M, Delmeire L, Schotte C, et al. The two-factorial symptom structure of post-traumatic stress disorder: depression-avoidance and arousal-anxiety. Psychiatry Res. 1998;81(2):195-210.

101. Asmundson G, Frombach I, McQuaid J, Pedrelli P, Lenox R, Stein M. Dimensionality of posttraumatic stress symptoms: A confirmatory factor analysis of DSM-IV symptom clusters and other symptom models. Behav Res Ther. 2000;38(2):203-214.

102. Asmundson G, Wright K, McCreary D, Pedlar D. Post-traumatic stress disorder symptoms in United Nations peacekeepers: An examination of factor structure in peacekeepers with and without chronic pain. Cognit Behav Ther. 2003;32(1):2637.

103. Cordova M, Studts J, Hann D, Jacobsen P, Andrykowski M. Symptom structure of PTSD following breast cancer. J Trauma Stress. 2000;13(2):301-319.

104. Lauterbach D, Vrana S, King D, King L. Psychometric properties of the Civilian Version of the Mississippi PTSD Scale. J Trauma Stress. 1997;10(3):499-514.

105. King D, Leskin G, King L, Weathers F. Confirmatory factor analysis of the Clinician-Administered PTSD Scale: Evidence for the dimensionality of posttraumatic stress disorder. Psychological Assessment. 1998;10(2):90-96.

106. DuHamel K, Ostroff J, Ashman T, et al. Construct validity of the Posttraumatic Stress Disorder Checklist in cancer survivors: Analyses based on two samples. Psychol Assess. 2004;16(3):255-266.

107. Larsson G. Dimensional analysis of the Impact of Event Scale using structural equation modeling. J Trauma Stress. 2000;13(2):193-205.

108. Ruscio A, Ruscio J, Keane T. The latent structure of posttraumatic stress disorder: A taxometric investigation of reactions to extreme stress. J Abnorm Psychol. 2002;111(2):290-301.

109. Weiss D. The Impact of Event Scale-Revised. In: Weiss D, Marmar C, eds. The Impact of Event Scale-Revised. New York: Guilford; 1997:168-189.

110. Stein M, Walker J, Hazen A, Forde D. Full and partial posttraumatic stress disorder: Findings from a community survey. Am J Psychiatry. 1997;154(8):1114-1119.

111. Schnurr P, Ford J, Friedman M, Green B, Dain B, Sengupta A. Predictors and outcomes of posttraumatic stress disorder in World War II veterans exposed to mustard gas. J Consult Clin Psychol. 2000;68(2):258-268.

112. Foa E, Riggs D, Dancu C, Rothbaum B. Reliability and validity of a brief instrument for assessing posttraumatic stress disorder. J Trauma Stress. 1993;6:459-473.

113. Weiss D, Marmar C. The Impact of Event Scale-Revised. In: Wilson J, Keane T, eds. Assessing Psychological Trauma and PTSD. New York: Guildford Press; 1996:399-411.

114. Quinnell F, Hyana M. Convergent and discriminant validity of the Perinatal PTSD Questionnaire (PPQ): A preliminary study. J Trauma Stress. 1999;12(1):193-199. 
115. Scott M, Stradling S, Lee S. The utility and accuracy of three self-report measures of posttraumatic stress disorder. Paper presented at: 13th International Conference of the Internatinal Society for the Study of Traumatic Stress; November, 1997; Montreal, Ontario.

116. Humphreys L, Westerink J, Giarratano L, Brooks R. An intensive treatment program for chronic posttraumatic stress disorder: 2-year outcome data. Aust $N Z$ J Psychiatry. 1999;33(6):848-854.

117. Scheck M, Schaeffer J, Gillette C. Brief psychological intervention with traumatized young women: The efficacy of eye movement desensitization and reprocessing. J Trauma Stress. 1998;11(1):25-44.

118. Murdoch M, Hodges J, Cowper D, Sayer N. Regional variation and other correlates of Department of Veterans Affairs (VA) disability awards for posttraumatic stress disorder. Med Care. 2005;43(2):112-121.

119. Weathers F, Litz B, Huska J, Keane T. PCL-C for DSM-IV. Boston: National Center for PTSD--Behavioral Sciences Division;1994.

120. Orlando M, Marshall G. Differential itemfunctioning in a Spanish translation of the PTSD Checklist: Detection and evaluation of impact. Psychol Assess. 2002;14(1):50-59.

121. Escobar J, Randolph E, Puente G, et al. Post-traumatic stress disorder in Hispanic Vietnam veterans: Clinical phenomenology and sociocultural characteristics. $J$ Nerv Ment Dis. 1983;171:585-596.

122. Hough R, Canino G, Abueg F, Gusman F. PTSD and related stress disorders among Hispanics. In: Marsella A, Friedman M, Gerrity E, Scurfield R, eds. Ethnocultural Aspects of Posttraumatic Stress Disorder. Washington, DC: American Psychological Association; 1996:301-338.

123. Norris F, Weisshaar D, Conrad M, Diaz E, Murphy A, Ibanez G. A qualitative analysis of posttraumatic stress among Mexican victims of disaster. J Trauma Stress. 2001;14(4):741-756.

124. Rosenheck R, Fontana A. Ethnocultural variations in service use among veterans suffering from PTSD. In: Marsella A, Friedman M, Gerrity E, et al., eds. Ethnocultural Aspects of Posttraumatic Stress Disorder. Washington, DC: American Psychological Association; 1996:483-504.

125. Glover H, Pelesky C, Bruno R, Sette R. Post-traumatic stress disorder conflicts in Vietnam combat veterans: A confirmatory factor analytic study. J Trauma Stress. 1990;3(4):573-591.

126. Keane T, Caddell J, Taylor K. Mississippi Scale for combat-related posttraumatic stress disorder: Three studies in reliability and validity. J Consult Clin Psychol. 1988;56(1):85-90.

127. Watson CG, Kucala T, Juba M, Manifold V, Anderson PE, Anderson D. A factor analysis of the DSM-III post-traumatic stress disorder criteria. J Clin Psychol. 1991;47(2):205-214.

128. Watson C, Juba M, Manifold V, Kucala T, Anderson P. The PTSD Interview: Rationale, description, reliablity, and concurrent validity of a DSM-III-based technique. J Clin Psychol. 1991;47(1):179-188. 
129. Wilson J, Krauss G. The Vietnam Stress Inventory: A scale to assess war stress and post-traumatic stress disorder among Vietnam veterans. Cleveland: Cleveland State University; 19811981.

130. Hovens J, van der Ploeg H, Bramsen I, Klaarenbeek M, Schreuder J, Rivero V. The development of the Self-Rating Inventory for Posttraumatic Stress Disorder. Acta Psychiatr Scand. 1994;90:172-183.

131. Keane T. Symptomatology of Vietnam veterans with posttraumatic stress disorder. In: Davidson J, Foa E, eds. Posttraumatic Stress Disorder: DSM-IV and Beyond. Washington, DC: American Psychiatric Press; 1993:99-111.

132. Spitzer R, Williams J, Gibbon M. Structured clinical interview for DSM-III-R-Patient Version (SCID-P, 4-1-87). New York: New York State Psychiatric Institute; 1987.

133. King L, King D, Leskin G, Foy D. The Los Angeles Symptom Checklist: A selfreport measure of posttraumatic stress disorder. Assessment. 1995;2(1):1-17.

134. McFall M, Smith D, MacKay P, Tarver D. Reliability and validity of Mississippi Scale for Combat-Realted Posttraumatic Stress Disorder. Psychol Assess. 1990;2(2):114-121.

135. Welner Z, Reich W, Herjanic B, Jung K, Amado H. Reliability, validity, and parent-child agreement studies of the Diagnostic Interview for Children and Adolescents. J Am Acad Child Adolesc Psychiatr. 1987;26:649-653.

136. Spitzer R, Williams J, Gibbon M, First M. Structured clinical interview for DSMIII-R--Patient Edition (with psychotic screen). Washington, DC: American Psychiatric Press; 1990.

137. Amdur R, Liberzon I. The structure of posttraumatic stress disorder symptoms in combat veterans: A confirmatory factor analysis of the Impact of Event Scale. $J$ Anxiety Disord. 2001;15(4):345-357.

138. Horowitz M, Wilner N, Alvarez W. Impact of Event Scale: A measure of subjective stress. Psychosom Med. 1979;41:209-218.

139. Frederick C. Children traumatized by catastrophic situations. In: Eth S, Pynoos R, eds. Post-traumatic stress disorder in children. Washington, DC: American Psychiatric Press; 1985:73-99.

140. Asukai N, Kato H, Kawamura N, et al. Reliability and validity of the Japaneselanguage version of the Impact of Event Scale-Revised (IES-R-J): Four studies of different traumatic events. J Nerv Ment Dis. 2002;190(3):175-182.

141. Briggs L, Joyce P. What determines post-traumatic stress disorder symptomatology for survivors of childhood sexual abuse? Child Abuse Negl. 1997;21(6):575-582.

142. Coons P, Cole C, Pellow T, Milstein V. Symptoms of post-traumatic stress and dissociation in women victims of abuse. In: Kluft R, ed. Incest related syndromes of adult psychopathology. Washington, DC: American Psychiatric Press; 1990:205-225.

143. Blake D, Weathers F, Nagy L, et al. The development of a clinician-administered PTSD scale. J Trauma Stress. 1995;8(1):75-90.

144. Creamer M, Bell R, S F. Psychometric properties of the Impact of Event Scale Revised. Behav Res Ther. 2003;41(12):1489-1496. 
145. Gaffney M. Factor analysis of treatment response in posttraumatic stress disorder. J Trauma Stress. 2003;16(1):77-80.

146. Hamada R, Hamada V, Yanagida E, Chemtob C. Assessment of elementary school children for disaster-related posttraumatic stress disorder symptoms: The Kauai Recovery Index. J Nerv Ment Dis. 2003;191(4):268-272.

147. McDonald S, Beckham J, Morey R, Marx C, Tupler L, Calhoun P. Factorial invariance of posttraumatic stress disorder symptoms across three veteran samples. J Trauma Stress. 2008;21(3):309-317.

148. Norris F, Perilla J. The Revised Civilian Mississippi Scale for PTSD: Reliability, validity, and cross-language stability. J Trauma Stress. 1996;9(2):285-298.

149. Scott W, Dua J. Development of a scale to assess posttraumatic stress disorder. International J Stress Management. 1999;6(3):149-165.

150. Smith M, Redd W, DuHamel K, Vickberg S, Ricketts P. Validation of the PTSD Checklist-Civilian Version in Survivors of Bone Marrow Transplantation. $J$ Trauma Stress. 1999;12(3):485-500.

151. Stewart A, Steiman M, Cauce A, Cochran B, Whitbeck L, Hoyt D. Victimization and posttraumatic stress disorder among homeless adolescents. J Am Acad Child Adolesc Psychiatr. 2004;43(3):325-331.

152. Ventureyra V, Yao S, Cottraux J, Note I, de Mey-Guillard C. The validation of the Posttraumatic Stress Disorder Checklist Scale in posttraumatic stress disorder and nonclinical subjects. Psychother Psychosom. 2002;71:47-53.

153. Cottraux J. French version of the PTSD Checklist Scale, 1996. In: Cottraux J, ed. Les therapies comportementales et cognitives. Paris: Masson; 1998.

154. Brunet A, St-Hilare A, Hjehel L, King S. Validation of a French version of the Impact of Event Scale-Revised. Can J Psychiatry. 2003;48(1):56-61.

155. Callahan J, Hynan M. An exploratory factor analysis of the Perinatal Posttraumatic Stress Disorder Questionnaire, Revised. J Perinatol. 2003;23:169178.

156. Shevlin M, Hunt N, Robbins I. A confirmatory factor analysis of the Impact of Event Scale using a sample of World War II and Korean War veterans. Psychol Assess. 2000;12(4):414-417. 


\section{Figure}

\section{Scree Plot}

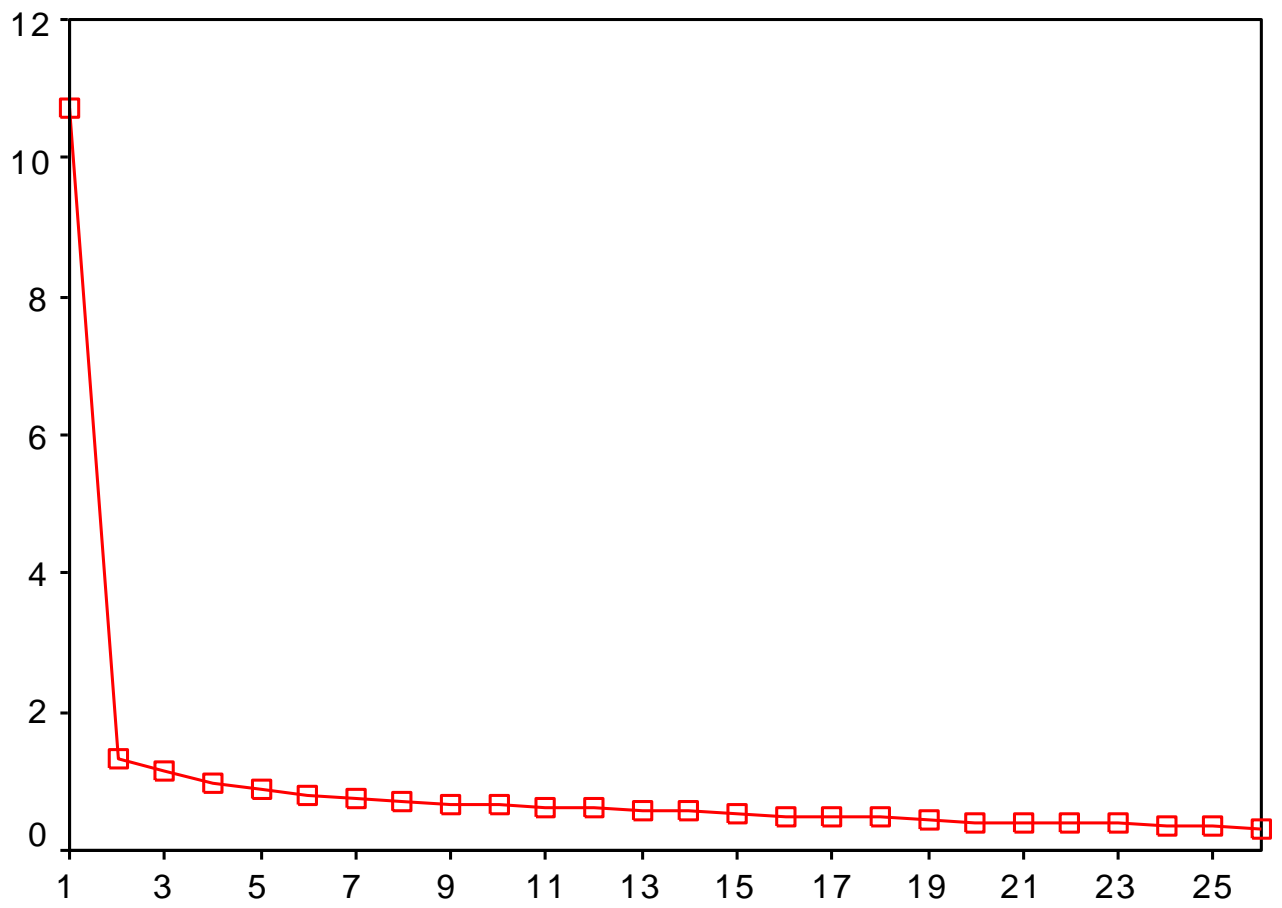

Component Number 
Table 1. Component Analysis of Entire Sample's Responses to the Penn Inventory for PTSD

\begin{tabular}{|c|c|c|}
\hline \multirow[t]{2}{*}{ Item's content (Group Number): } & \multicolumn{2}{|c|}{ Component Loadings } \\
\hline & $\begin{array}{l}\text { Component } 1 \\
\text { Alienation } \\
\text { and } \\
\text { Numbing } \\
\end{array}$ & $\begin{array}{c}\text { Component } 2 \\
\text { Re-Experiencing } \\
\text { and Sleep } \\
\text { Disturbance }\end{array}$ \\
\hline Hard to shape goals (18) & .71 & .27 \\
\hline Unclear goals (23) & .70 & .24 \\
\hline Poor self-knowledge (15) & .68 & .31 \\
\hline Able to enjoy things with others (3) & .63 & .25 \\
\hline Achieving things I want (20) & .63 & .32 \\
\hline Feel more confused about my life (14) & .62 & .41 \\
\hline Not feeling understood (25) & .62 & .44 \\
\hline Not caring about actions' consequences (2) & .57 & .17 \\
\hline Feeling different from others (1) & .56 & .41 \\
\hline Worried about being understood (5) & .56 & .23 \\
\hline Feeling distracted (9) & .54 & .42 \\
\hline Difficulty concentrating (11) & .51 & .47 \\
\hline Meaning from spiritual life (10) & .51 & .05 \\
\hline Difficult to control anger (16) & .51 & .25 \\
\hline Trouble coping with unwanted thoughts (19) & .50 & .48 \\
\hline Afraid to show anger/violence (6) & .47 & .35 \\
\hline Troubling nightmares (13) & .22 & .75 \\
\hline Intense trauma experience(s) (17) & .14 & .72 \\
\hline Flashback severity (8) & .12 & .72 \\
\hline Sleep difficulty/nightmares (21) & .30 & .65 \\
\hline $\begin{array}{l}\text { Anxious when confronted with trauma } \\
\text { reminders ( } 7 \text { ) }\end{array}$ & .37 & .61 \\
\hline Intrusive, bad memories (24) & .39 & .60 \\
\hline Feeling jumpy or uptight (4) & .50 & .51 \\
\hline Unable to share and process traumas (12) & .40 & .44 \\
\hline Unable to grieve for others (26) & .33 & .44 \\
\hline Trouble remembering things (22) & .39 & .42 \\
\hline Eigen Value & 10.7 & 1.3 \\
\hline Variance Explained & $41.2 \%$ & $5.0 \%$ \\
\hline
\end{tabular}

Note: $\mathrm{N}=3,337$. Results are of a Principal Component Analysis extraction with Varimax rotation (with Kaiser Normalization). Rotation converged after 3 iterations. 
Table 2. "Alienation and Numbing" (Component 1) Correlations across Race/Ethnicity, Gender, and Trauma Type

\begin{tabular}{llllllllc}
\hline Category & \multicolumn{9}{c}{ Race/ethnicity } & & \multicolumn{2}{c}{ Gender } & \multicolumn{2}{c}{ Military Trauma Type } \\
\cline { 2 - 9 } & White & Black & $\begin{array}{c}\text { American } \\
\text { Indian }\end{array}$ & Hispanic & Men & Women & Combat & $\begin{array}{c}\text { Sexual } \\
\text { Assault }\end{array}$ \\
& $\mathrm{n}=2,444$ & $\mathrm{n}=560$ & $\mathrm{n}=233$ & $\mathrm{n}=179$ & $\mathrm{n}=1,655$ & $\mathrm{n}=1,682$ & $\mathrm{n}=2,059$ & $\mathrm{n}=1,264$ \\
\hline White & 1.00 & & & & & & & \\
Black & $.91 * * *$ & 1.00 & & & & & & \\
American Indian & $.84^{* * *}$ & $.80^{* * *}$ & 1.00 & & & & \\
Hispanic & $.68^{* * *}$ & $.50^{* * *}$ & $.60^{* * *}$ & 1.00 & & & \\
Men & $.88^{* * *}$ & $.98^{* * *}$ & $.75^{* * *}$ & $.41^{* * *}$ & 1.00 & & \\
Women & $.99^{* * *}$ & $.86^{* * *}$ & $.82^{* * *}$ & $.73^{* * *}$ & $.82^{* * *}$ & 1.00 & & \\
Combat-Exposed & $.97^{* * *}$ & $.98^{* * *}$ & $.83^{* * *}$ & $.54^{* * *}$ & $.97^{* * *}$ & $.93^{* * *}$ & 1.00 & \\
In-Service Sexual & $.99^{* * *}$ & $.85^{* * *}$ & $.83^{* * *}$ & $.75^{* * *}$ & $.80^{* * *}$ & $1.00^{* * *}$ & $.92^{* * * *}$ & 1.00 \\
Assault & & & & & & & & \\
\hline
\end{tabular}

$* * * \mathrm{p}<0.001$ 
Component Structure of the Penn Inventory 25

Table 3. "Alienation and Numbing" (Component 1) Correlations across Service Eras

\begin{tabular}{lcccccc}
\hline Category & World War II & $\begin{array}{c}\text { Korean } \\
\text { Conflict } \\
\mathrm{N}=102\end{array}$ & $\begin{array}{c}\text { Vietnam } \\
\text { Conflict } \\
\mathrm{N}=1664\end{array}$ & $\begin{array}{c}\text { Post- } \\
\text { Vietnam Era } \\
\mathrm{N}=603\end{array}$ & $\begin{array}{c}\text { Gulf War } \\
\mathrm{I}\end{array}$ & $\begin{array}{c}\text { Post-Gulf War } \\
\mathrm{N}=523\end{array}$ \\
\hline World War II & 1.00 & & & & & $\mathrm{~N}=209$ \\
Korean Conflict & $.98^{* * *}$ & 1.00 & & & & \\
Vietnam Conflict & $.84^{* * *}$ & $.87^{* * *}$ & 1.00 & & & \\
Post-Vietnam Era & $.82^{* * *}$ & $.85^{* * *}$ & $.99^{* * *}$ & 1.00 & & \\
Gulf War & $.85^{* * *}$ & $.87^{* * *}$ & $.99^{* * *}$ & $.99^{* * *}$ & 1.00 & \\
Post-Gulf War & $.84^{* * *}$ & $.88^{* * *}$ & $.96^{* * *}$ & $.96^{* * * *}$ & $.95 * * *$ & 1.00 \\
\hline
\end{tabular}

$* * * \mathrm{p}<0.001$ 
Component Structure of the Penn Inventory 26

Table 4. "Re-experiencing and Sleep Disturbances" (Component 2) Correlations across Race, Gender, and Trauma Type

\begin{tabular}{|c|c|c|c|c|c|c|c|c|}
\hline \multirow[t]{3}{*}{ Category } & \multicolumn{4}{|c|}{ Race/ethnicity } & \multicolumn{2}{|c|}{ Gender } & \multicolumn{2}{|c|}{ Military Trauma Type } \\
\hline & White & Black & American & Hispanic & Men & Women & Combat & Sexual \\
\hline & & $\mathrm{n}=560$ & $\begin{array}{c}\text { Indian } \\
\mathrm{n}=233\end{array}$ & & & & & $\begin{array}{c}\text { Assault } \\
\mathrm{n}=1,264\end{array}$ \\
\hline White & 1.00 & & & & & & & \\
\hline Black & $.87 * * *$ & 1.00 & & & & & & \\
\hline American Indian & $.88 * * *$ & $.80 * * *$ & 1.00 & & & & & \\
\hline Hispanic & $.45 * * *$ & $.29 * * *$ & $.70 * * *$ & 1.00 & & & & \\
\hline Men & $.85 * * *$ & $.98 * * *$ & $.78 * * *$ & $.22 * * *$ & 1.00 & & & \\
\hline Women & $.99 * * *$ & $.82 * * *$ & $.90 * * *$ & $.55 * * *$ & $.79 * * *$ & 1.00 & & \\
\hline Combat- & $.96 * * *$ & $.97 * * *$ & $.84 * * *$ & $.30 * * *$ & $.96 * * *$ & $.93 * * *$ & 1.00 & \\
\hline Exposed & & & & & & & & \\
\hline In-Service & $.98 * * *$ & $.81 * * *$ & $.92 * * *$ & $.61 * * *$ & $.77 * * *$ & $1.0 * * *$ & $.89 * * *$ & 1.00 \\
\hline Sexual Assault & & & & & & & & \\
\hline
\end{tabular}


Table 5. "Re-experiencing and Sleep Disturbances" (Component 2) Correlations across Service Eras

\begin{tabular}{lcccccc}
\hline Category & World War II & $\begin{array}{c}\text { Korean } \\
\text { Conflict }\end{array}$ & $\begin{array}{c}\text { Vietnam } \\
\text { Conflict }\end{array}$ & $\begin{array}{c}\text { Post- } \\
\text { Vietnam } \\
\text { Era }\end{array}$ & Gulf War I & $\begin{array}{c}\text { Post-Gulf } \\
\text { War I }\end{array}$ \\
\hline World War II & 1.00 & $\mathrm{n}=102$ & $\mathrm{n}=1,664$ & $\mathrm{n}=603$ & $\mathrm{n}=523$ & $\mathrm{n}=209$ \\
Korean Conflict & $.97 * * *$ & 1.00 & & & & \\
Vietnam Conflict & $.78 * * *$ & $.80 * * *$ & 1.00 & & & \\
Post-Vietnam Era & $.80^{* * *}$ & $.80 * * *$ & $.99 * * *$ & 1.00 & & \\
Gulf War I & $.82 * * *$ & $.82 * * *$ & $.98 * * *$ & $.99 * * *$ & 1.00 & \\
Post-Gulf War I & $.83 * * *$ & $.84 * * *$ & $.94 * * *$ & $.94 * * *$ & $.93 * * *$ & 1.00 \\
\hline
\end{tabular}

$* * * \mathrm{p}<0.001$ 
Table 6. Summary of PTSD Factor Analysis Results through 2008

\begin{tabular}{|c|c|c|c|c|}
\hline Authors & Sample* & $\begin{array}{c}\text { Factor } \\
\text { Analysis Type }\end{array}$ & Scale Used & Factors Extracted \\
\hline
\end{tabular}

\section{Using DSM-III Criteria for PTSD:}

\begin{tabular}{|c|c|c|c|c|}
\hline $\begin{array}{l}\text { Glover et al. }{ }^{125} \\
\text { DSM-III }\end{array}$ & $\begin{array}{l}339 \text { male Vietnam } \\
\text { combat Veterans with a } \\
\text { diagnosis of PTSD }\end{array}$ & $\begin{array}{l}\text { Exploratory } \\
\text { and } \\
\text { Confirmatory }\end{array}$ & $\begin{array}{l}\text { Vietnam-Related } \\
\text { Experiences } \\
\text { Questionnaire }\end{array}$ & $\begin{array}{ll}\text { 1. } & \text { Vulnerability } \\
\text { 2. } & \text { Guilt } \\
\text { 3. } & \text { Dreams of Death/ Destruction } \\
\text { 4. } & \text { Depression } \\
\text { 5. } & \text { Rebelliousness }\end{array}$ \\
\hline
\end{tabular}

\begin{tabular}{|c|c|c|c|c|}
\hline $\begin{array}{l}\text { Hendrix et al. }{ }^{93} \\
\text { DSM-III but } \\
\text { has } 4 \text { avoidance } \\
\text { questions }\end{array}$ & $\begin{array}{l}139 \text { male and } 4 \text { female } \\
\text { Vietnam Veterans }\end{array}$ & Exploratory & $\begin{array}{l}\text { Purdue Post-Traumatic } \\
\text { Stress Scale } \\
92\end{array}$ & $\begin{array}{l}\text { 1. Arousal } \\
\text { 2. Avoidance } \\
\text { 3. Global Perception of Stress }\end{array}$ \\
\hline \multirow[t]{2}{*}{$\begin{array}{l}\text { Hovens et al. } \\
\text { DSM-III }\end{array}$} & $\begin{array}{l}967 \text { male and female } \\
\text { Dutch resistance fighters }\end{array}$ & Exploratory & $\begin{array}{l}\text { The Dutch PTSD } \\
\text { Scale }{ }^{9}\end{array}$ & $\begin{array}{l}\text { 1. Intrusive War memories and } \\
\text { Accompanying Sleep } \\
\text { Problems } \\
\text { 2. General Physiological Arousal } \\
\text { 3 Detachment from other people } \\
\text { 4. Rage } \\
\text { 5. Active Confrontation with } \\
\text { War Stimuli } \\
\text { 6. Guilt }\end{array}$ \\
\hline & $\begin{array}{l}\text { Subgroup analysis of the } \\
144 \text { women }\end{array}$ & Exploratory & & $\begin{array}{l}\text { All factors listed above plus: } \\
\text { 7. "Concentration Problems" } \\
\text { 8. "Lack of Interest" }\end{array}$ \\
\hline
\end{tabular}

\begin{tabular}{|c|c|c|c|c|}
\hline $\begin{array}{l}\text { Keane et al. } \\
\text { DSM-III }\end{array}$ & $\begin{array}{l}362 \text { male Vietnam } \\
\text { Veterans help-seeking } \\
\text { Veterans }\end{array}$ & Exploratory & $\begin{array}{l}\text { Mississippi Scale for } \\
\text { Combat-Related PTSD } \\
126\end{array}$ & $\begin{array}{l}\text { 1. Intrusive Thoughts/ } \\
\text { Depression/ Suicidal } \\
\text { 2. Interpersonal Adjustment } \\
\text { Problems } \\
\text { 3. Lability of Affect/Memory } \\
\text { 4. Ruminative Features of PTSD } \\
\text { 5. Interpersonal Problems } \\
\text { 6. Sleep Problems }\end{array}$ \\
\hline
\end{tabular}

\begin{tabular}{|c|c|c|c|}
\hline $\begin{array}{l}\text { Silver et al. }{ }^{94} \\
\text { DSM-III }\end{array}$ & $\begin{array}{l}405 \text { Vietnam counseling- } \\
\text { seeking combat Veterans }\end{array}$ & Exploratory & $\begin{array}{l}\text { "list of symptoms . } \\
\text { drawn from clinical } \\
\text { observations and } \\
\text { research results" }\end{array}$ \\
\hline
\end{tabular}

The same 405 Vietnam Exploratory

1. Depression/Dysthymia

2. Survivor Guilt

3. Re-Experiencing

4. Numbed Responsiveness/ Detachment/Apprehension

Veterans plus 63

individuals seeking

counseling for personal

problems

1. Depression

2. Re-experiencing

3. Anger

4. Detachment 


\begin{tabular}{|c|c|c|c|c|}
\hline $\begin{array}{l}\text { Watson et al. }{ }^{127} \\
\text { DSM-III }\end{array}$ & $\begin{array}{l}131 \text { male Vietnam } \\
\text { Veterans with PTSD }\end{array}$ & Exploratory & $\begin{array}{l}\text { DSM-III PTSD } \\
\text { Interview } 128\end{array}$ & $\begin{array}{l}\text { 1. Intrusive Thoughts and Their } \\
\text { Effects } \\
\text { 2. Increased Arousal } \\
\text { 3. Impoverished Relationships (a } \\
\text { numbing/avoidance factor) } \\
\text { 4. Guilt } \\
\text { 5. Cognitive Interference }\end{array}$ \\
\hline
\end{tabular}

\section{Using DSM-III-R Criteria for PTSD:}

\begin{tabular}{|c|c|c|c|c|}
\hline \multirow[t]{2}{*}{$\begin{array}{l}\text { Davidson et } \\
\text { al. }{ }^{99} \\
\text { DSM-III-R }\end{array}$} & $\begin{array}{l}353 \text { male and female } \\
\text { survivors of } \\
\text { heterogeneous traumas } \\
\text { (e.g., combat, sexual } \\
\text { assault, natural disaster) }\end{array}$ & Exploratory & $\begin{array}{l}\text { Davidson Trauma } \\
\text { Scale }^{99}\end{array}$ & $\begin{array}{l}\text { 1. General Severity Factor } \\
\text { 2. Intrusion }\end{array}$ \\
\hline & $\begin{array}{l}\text { Subgroup of the } 67 \\
\text { subjects with PTSD } \\
\text { diagnosis }\end{array}$ & Exploratory & & $\begin{array}{l}\text { 1. General Severity Factor } \\
\text { 2. Reduced Enjoyment/ } \\
\text { Estrangement/Lack of Loving } \\
\text { Feeling/foreshortened Future } \\
\text { 3. Avoiding Activities/Insomnia } \\
\text { 4. Avoiding Thoughts, Feelings, } \\
\text { Situations } \\
\text { 5. Hyperarousal } \\
\text { 6. Amnesia }\end{array}$ \\
\hline
\end{tabular}

\begin{tabular}{|c|c|c|c|c|}
\hline $\begin{array}{l}\text { Foa et al. }^{16} \\
\text { DSM-III-R }\end{array}$ & $\begin{array}{l}72 \text { female rape victims } \\
\& 86 \text { female victims of } \\
\text { non-sexual assault }\end{array}$ & Exploratory & $\begin{array}{l}\text { The PTSD Symptom } \\
\text { Scale } 112\end{array}$ & $\begin{array}{l}\text { 1. Arousal/Avoidance } \\
\text { 2. Numbing } \\
\text { 3. Intrusion }\end{array}$ \\
\hline $\begin{array}{l}\text { Hovens et al. }{ }^{130} \\
\text { DSM-III-R }\end{array}$ & $\begin{array}{l}76 \text { Dutch men and } \\
\text { women with war-related } \\
\text { trauma and } 59 \text { Dutch } \\
\text { psychiatric outpatients }\end{array}$ & Exploratory & $\begin{array}{l}\text { The Self-Rating } \\
\text { Inventory for } \\
\text { Posttraumatic Stress } \\
\text { Disorder } 130\end{array}$ & $\begin{array}{l}\text { 1. Numbing } \\
\text { 2. Intrusion } \\
\text { 3. Avoidance } \\
\text { 4. Sleeping Problems }\end{array}$ \\
\hline
\end{tabular}




\begin{tabular}{|c|c|c|c|c|}
\hline $\begin{array}{l}\text { Keane et al. } \\
\text { DSM-III-R }\end{array}$ & $\begin{array}{l}68 \text { Vietnam Veterans } \\
\text { with a PTSD diagnosis; } \\
\text { sample's gender } \\
\text { composition not } \\
\text { specified }\end{array}$ & Exploratory & $\begin{array}{l}\text { Structured Clinical } \\
\text { Interview for DSM- } \\
\text { III-R PTSD Module } \\
132\end{array}$ & $\begin{array}{l}\text { 1. Intrusive Experiences/Reliving } \\
\text { Experiences/Affect } \\
\text { Restriction/Hypervigilence } \\
\text { 2. Reactivity/Avoidance/Startle } \\
\text { 3. Irritability/Impaired } \\
\text { Concentration } \\
\text { 4. Diminished Interest/ } \\
\text { Detachment /Estrangement }\end{array}$ \\
\hline & & Exploratory & $\begin{array}{l}\text { Mississippi Scale for } \\
\text { Combat-Related PTSD } \\
126\end{array}$ & $\begin{array}{l}\text { 1. Re-experiencing/Reliving } \\
\text { Trauma/Nightmares } \\
\text { 2. Numbing/Restricted Affect/ } \\
\text { Anger/Irritability } \\
\text { 3. Impulse control/Destructive } \\
\text { Impulses } \\
\text { 4. Inability to concentrate/Enjoy } \\
\text { Activities or People in Life }\end{array}$ \\
\hline $\begin{array}{l}\text { King et al. }{ }^{97} \\
\text { DSM-III-R } \\
\text { Higher order } \\
\text { factor }\end{array}$ & $\begin{array}{l}2,272 \text { Vietnam theater } \\
\text { and era Veterans } \\
\text { (NVVRS respondents) } \\
\text { randomly divided into } 3 \\
\text { subsamples }\end{array}$ & Confirmatory & $\begin{array}{l}\text { Mississippi Scale for } \\
\text { Combat-Related PTSD } \\
126\end{array}$ & $\begin{array}{l}\text { Subsample 1: } \\
\text { 1. Single-factor solution } \\
\text { Subsamples } 2 \& 3 \text { : } \\
\text { 1. Re-experiencing/Situational } \\
\text { avoidance } \\
\text { 2. Withdrawal and numbing } \\
\text { 3. Arousal/Lack of behavioral or } \\
\text { 4. } \quad \text { Self-Persecution }\end{array}$ \\
\hline $\begin{array}{l}\begin{array}{l}\text { Lauterbach et } \\
\text { al. }{ }^{104}\end{array} \\
\text { DSM-III-R } \\
\text { Support for } \\
\text { higher order } \\
\text { factor using } 35 \\
\text { item version, } \\
\text { not the 39-item } \\
\text { version }\end{array}$ & $\begin{array}{l}440 \text { male and female } \\
\text { undergraduate college } \\
\text { students (previously } \\
\text { studied in }{ }^{43} \text { ) and } 402 \\
\text { introductory psychology } \\
\text { college students }\end{array}$ & Confirmatory & $\begin{array}{l}\text { The Civilian } \\
\text { Mississippi PTSD } \\
\text { Scale (35-item } \\
\text { version) }\end{array}$ & $\begin{array}{l}\text { 1. Re-Experiencing and } \\
\text { Situational Avoidance } \\
\text { 2. Withdrawal and numbing } \\
\text { 3. Arousal and Lack of } \\
\text { Behavioral or Emotional } \\
\text { Control } \\
\text { 4. Self-Persecution (Guilt and } \\
\text { Suicidality) }\end{array}$ \\
\hline $\begin{array}{l}\text { Maes et al. }{ }^{100} \\
\text { DSM-III-R } \\
\text { Support for } \\
\text { higher order } \\
\text { factor }\end{array}$ & $\begin{array}{l}130 \text { Antwerp hotel-fire } \\
\text { victims } \\
55 \text { Belgian car accident } \\
\text { victims }\end{array}$ & $\begin{array}{l}\text { Exploratory \& } \\
\text { Confirmatory }\end{array}$ & $\begin{array}{l}\text { Composite } \\
\text { International } \\
\text { Diagnostic Interview } \\
\text { PTSD Module }\end{array}$ & $\begin{array}{l}\text { 1. Depression/Avoidance } \\
\text { 2. Anxiety/Arousal }\end{array}$ \\
\hline
\end{tabular}




\begin{tabular}{|c|c|c|c|c|}
\hline $\begin{array}{l}\text { McFall et al. } \\
\text { DSM-III-R }\end{array}$ & $\begin{array}{l}101 \text { Vietnam combat } \\
\text { Veterans of with PTSD } \\
\text { and } 102 \text { Veterans with } \\
\text { substance use disorders } \\
\text { but no PTSD; sample's } \\
\text { gender composition not } \\
\text { specified }\end{array}$ & Exploratory & $\begin{array}{l}\text { Mississippi Scale for } \\
\text { Combat-Related PTSD } \\
96\end{array}$ & $\begin{array}{l}\text { 1. Intrusive Re-experiencing/ } \\
\text { Numbing-Avoidance } \\
\text { 2. Anger Discontrol/Lability } \\
\text { 3. Social Alienation }\end{array}$ \\
\hline \multirow[t]{2}{*}{$\begin{array}{l}\text { Sack et al. }{ }^{27} \\
\text { DSM-III-R }\end{array}$} & $\begin{array}{l}209 \text { Khmer refugees } \\
\text { aged 13-25 years }\end{array}$ & Exploratory & $\begin{array}{l}\text { Diagnostic Interview } \\
\text { for Children and } \\
\text { Adolescents }{ }^{135}\end{array}$ & $\begin{array}{l}\text { 1. Arousal } \\
\text { 2. Avoidance } \\
\text { 3. Intrusion } \\
\text { 4. Numbing }\end{array}$ \\
\hline & $\begin{array}{l}98 \text { study participants' } \\
\text { parents }\end{array}$ & Confirmatory & & $\begin{array}{l}\text { Same factors as the children's } \\
\text { responses }\end{array}$ \\
\hline $\begin{array}{l}\text { Taylor et al. }{ }^{91} \\
\text { DSM-III-R }\end{array}$ & $\begin{array}{l}103 \text { male and female } \\
\text { Canadian motor vehicle } \\
\text { accident survivors }\end{array}$ & Exploratory & $\begin{array}{l}\text { Structured Clinical } \\
\text { Interview for DSM- } \\
\text { III-R PTSD Module } \\
136\end{array}$ & $\begin{array}{l}\text { 1. Intrusion/Avoidance } \\
\text { 2. Hyperarousal/Numbing }\end{array}$ \\
\hline $\begin{array}{l}\text { DSM-III- } \\
\text { R/DSM-IV }\end{array}$ & $\begin{array}{l}419 \text { mostly male United } \\
\text { Nations peacekeepers } \\
\text { deployed from Canada to } \\
\text { Bosnia }\end{array}$ & Exploratory & $\begin{array}{l}\text { PTSD Symptom Scale } \\
112\end{array}$ & $\begin{array}{l}\text { 1. Intrusion/Avoidance } \\
\text { 2. Hyperarousal/Numbing }\end{array}$ \\
\hline $\begin{array}{l}\text { Vreven et al. } \\
\text { DSM-III-R } \\
\text { Tested } \\
\text { hierarchical } \\
\text { model }\end{array}$ & $\begin{array}{l}451 \text { non-Veteran men } \\
\text { and } 217 \text { non-Veterans } \\
\text { women who participated } \\
\text { in the National Vietnam } \\
\text { Veterans Readjustment } \\
\text { Study } 7,8\end{array}$ & Confirmatory & $\begin{array}{l}\text { The Civilian } \\
\text { Mississippi PTSD } \\
\text { Scale }\end{array}$ & $\begin{array}{l}\text { 1. Re-experiencing and } \\
\text { Situational Avoidance } \\
\text { 2. Withdrawal and Numbing } \\
\text { 3. Arousal/Lack of Control } \\
\text { 4 Self-persecution (guilt and } \\
\text { suicidality) }\end{array}$ \\
\hline
\end{tabular}

\section{Using DSM-IV Criterion for PTSD:}

\begin{tabular}{|c|c|c|c|c|}
\hline $\begin{array}{l}\text { Amdur et al. }{ }^{137} \\
\text { DSM-IV }\end{array}$ & $\begin{array}{l}195 \text { male combat } \\
\text { Veterans with PTSD }\end{array}$ & Confirmatory & ${ }_{138}^{\text {Impact of Event Scale }}$ & $\begin{array}{l}\text { 1. Intrusion } \\
\text { 2. Effortful Avoidance } \\
\text { 3. Sleep Disturbance } \\
\text { 4. Emotional Numbing }\end{array}$ \\
\hline $\begin{array}{l}\text { DSM-III-R and } \\
\text { DSM-IV }\end{array}$ & $\begin{array}{l}\text { exposed to Hurricane } \\
\text { Hugo }\end{array}$ & & $\begin{array}{l}\text { Index } \\
\text { For Children } 139\end{array}$ & 3. Numbing/Passive Avoidance \\
\hline
\end{tabular}


Component Structure of the Penn Inventory 32

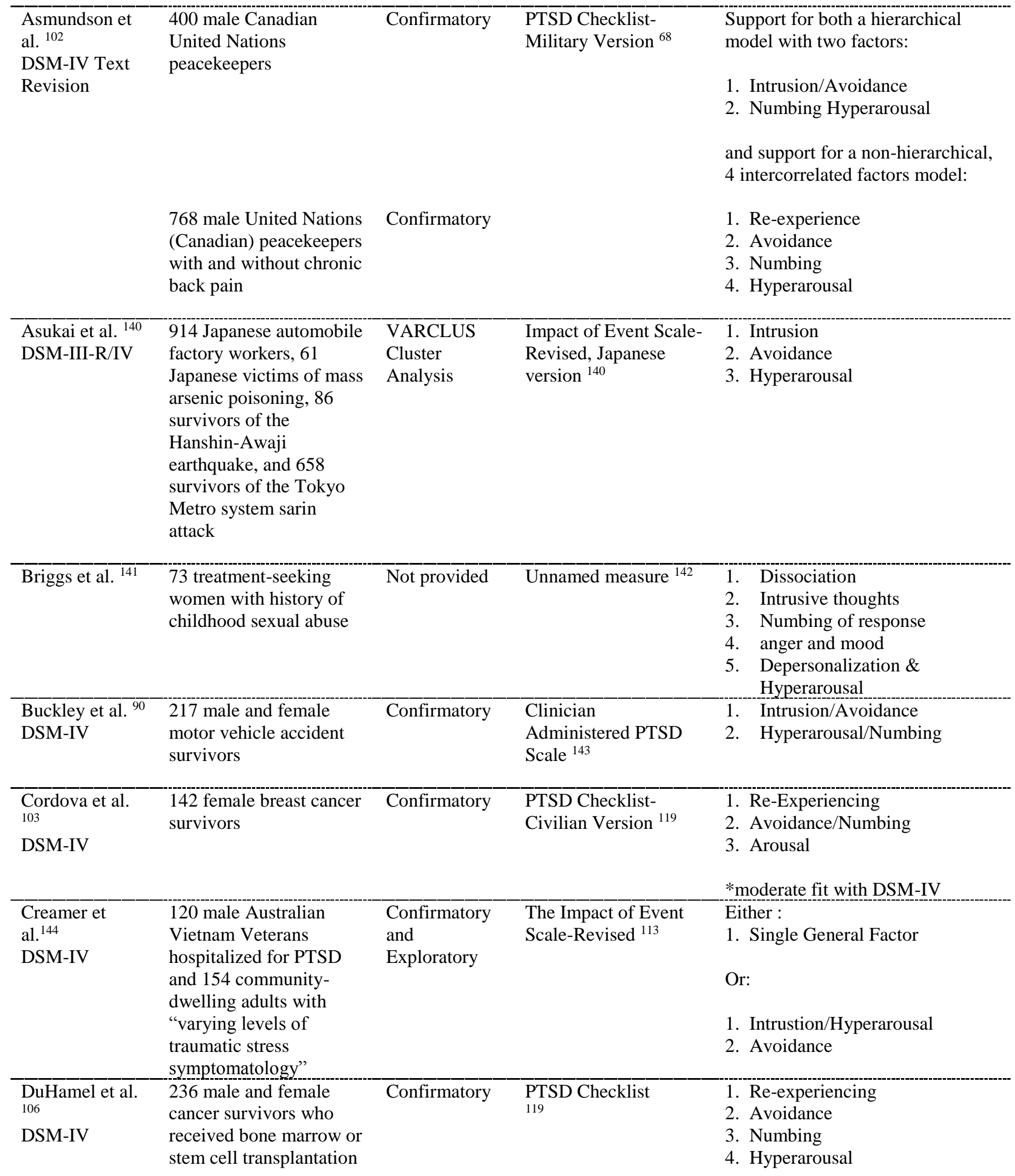




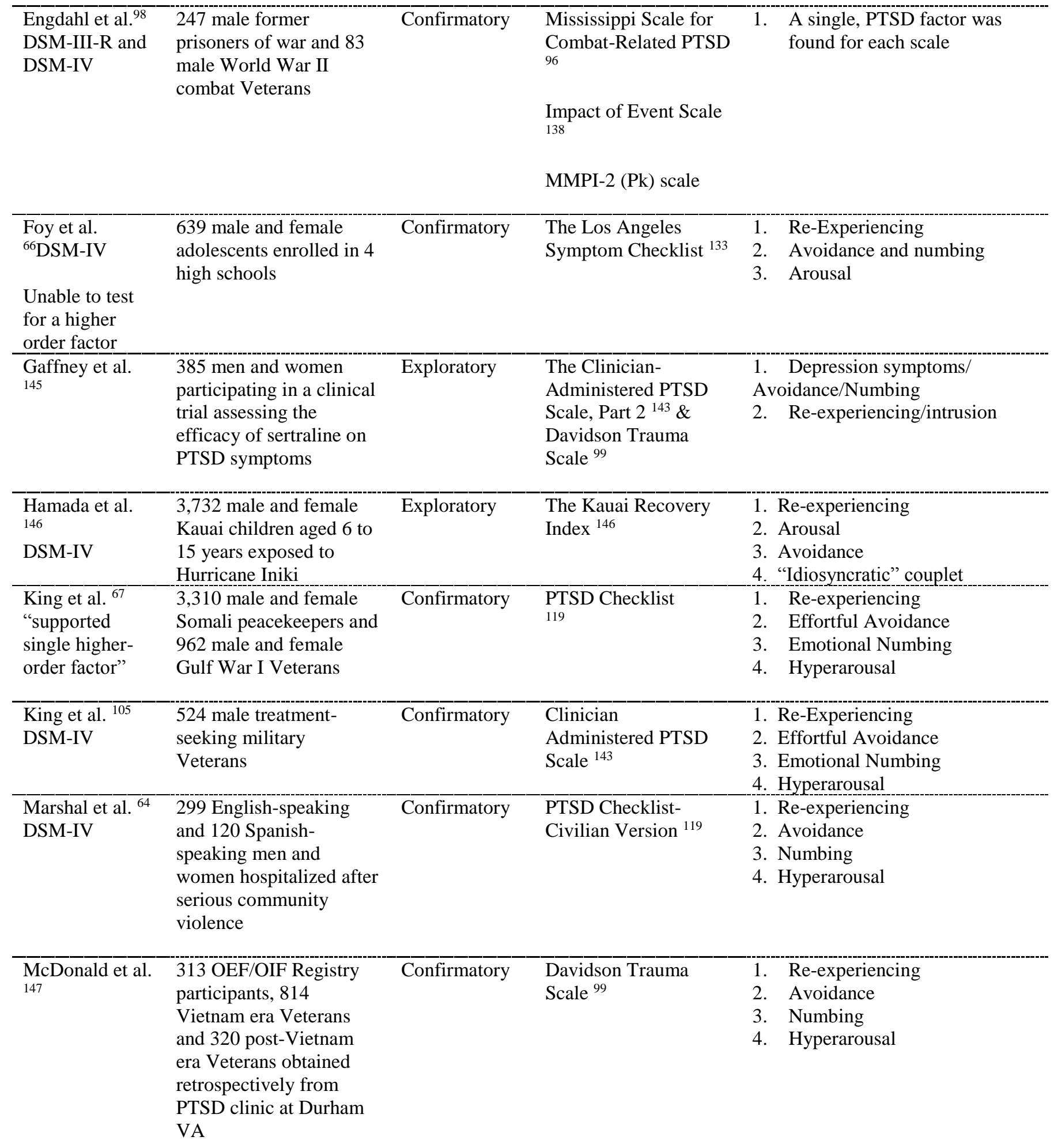


Component Structure of the Penn Inventory 34

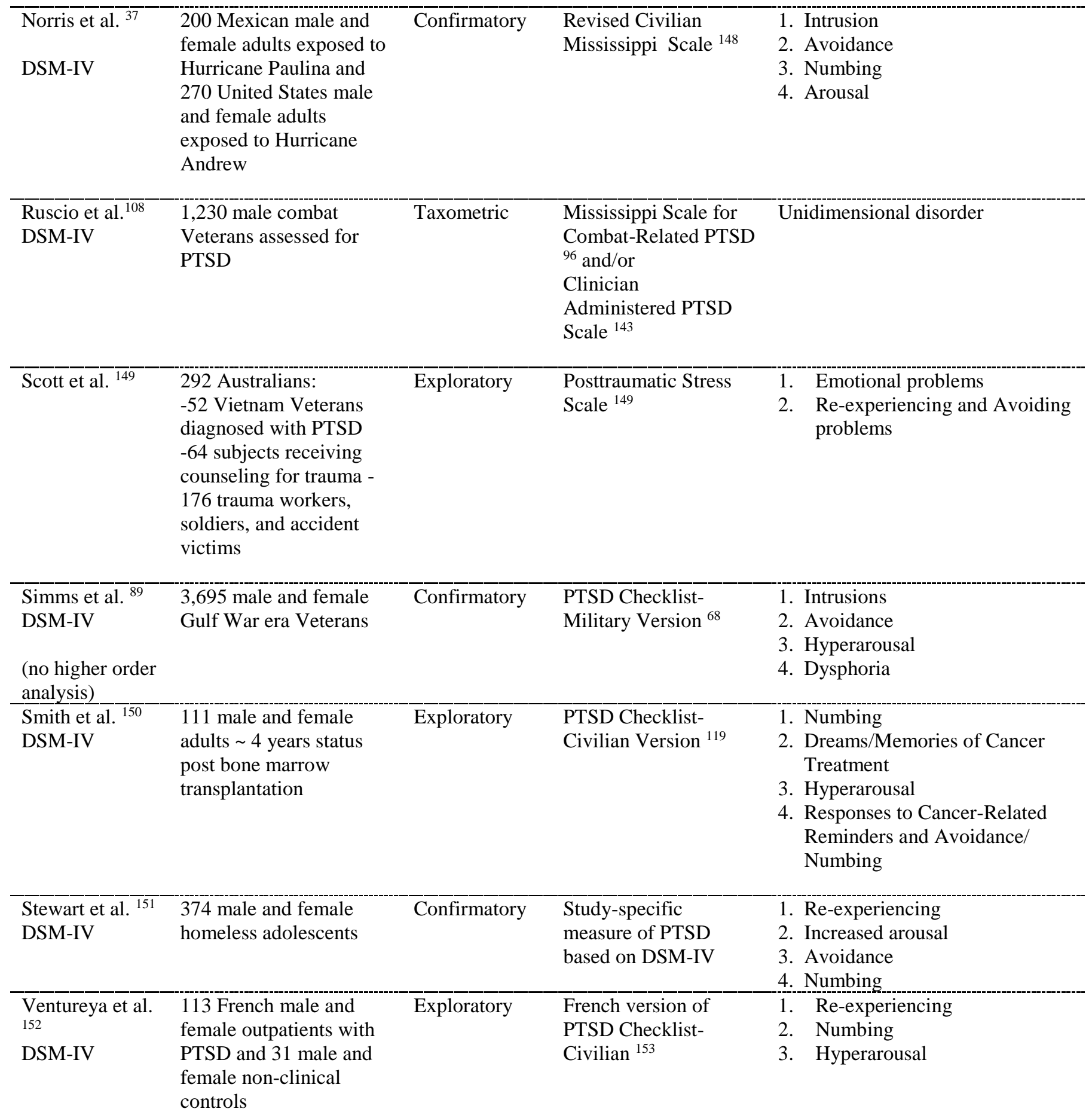




\begin{tabular}{|c|c|c|c|c|}
\hline $\begin{array}{l}\text { McDonald et al. } \\
147 \\
\text { DSM-IV }\end{array}$ & $\begin{array}{l}313 \text { OEF/OIF } \\
\text { participants in the } \\
\text { Durham VA } \\
\text { Postdeploymnet Mental } \\
\text { Health (OEF/OIF } \\
\text { Registry) plus } 814 \\
\text { Vietnam-era Veterans } \\
\text { and } 320 \text { post-Vietnam } \\
\text { Veterans (mostly Gulf } \\
\text { War I era) }\end{array}$ & $\begin{array}{l}\text { Multigroup } \\
\text { Confirmatory }\end{array}$ & $\begin{array}{l}\text { Davidson Trauma } \\
\text { Scale } \\
99\end{array}$ & $\begin{array}{l}\text { For all three groups, a } 4 \text {-factor } \\
\text { model with intercorrelations } \\
\text { between factors tended to have the } \\
\text { best fit (better than Simms et al.'s } \\
4 \text { factor model with "dysphoria" as } \\
\text { one of the factors }{ }^{89} \text { ): } \\
\text { 1. Re-experiencing } \\
\text { 2. Avoidance ( } 2 \text { items) } \\
\text { 3. Numbing } \\
\text { 4. Hyperarousal } \\
\text { Metric invariance was supported } \\
\text { for Vietnam and Gulf War I } \\
\text { Veterans but not between these } \\
\text { two groups and the OEF/OIF } \\
\text { sample. Metric invariance: same } \\
\text { number of factors, identical } \\
\text { corresponding items in those } \\
\text { factors, and equivalent factor } \\
\text { loadings for each item. Configural } \\
\text { invariance was shown for all three } \\
\text { groups, signifying the same } \\
\text { number of factors and the same } \\
\text { items in each factor. }\end{array}$ \\
\hline
\end{tabular}

\section{DSM criterion not specified:}

\begin{tabular}{|c|c|c|c|c|}
\hline $\begin{array}{l}\text { Brunet et al. }{ }^{154} \\
\text { DSM not } \\
\text { specified }\end{array}$ & $\begin{array}{l}223 \text { Canadian franco- } \\
\text { phone women who were } \\
\text { pregnant during a deadly } \\
1998 \text { ice storm or who } \\
\text { became pregnant shortly } \\
\text { thereafter }\end{array}$ & Exploratory & $\begin{array}{l}\text { Impact of Event Scale- } \\
\text { Revised-French } \\
\text { version } 154\end{array}$ & $\begin{array}{l}\text { 1. Hyperarousal } \\
\text { 2. Avoidance } \\
\text { 3. Intrusion }\end{array}$ \\
\hline $\begin{array}{l}\text { Callahan et al. } \\
155 \\
\text { DSM version } \\
\text { not specified }\end{array}$ & $\begin{array}{l}89 \text { mothers and fathers } \\
\text { of medically fragile } \\
\text { infants }\end{array}$ & Exploratory & $\begin{array}{l}\text { The Perinatal PTSD } \\
\text { Questionnaire II }{ }^{155}\end{array}$ & $\begin{array}{l}\text { 1. Symptom Severity } \\
\text { 2. Intrusion/Avoidance/Guilt } \\
\text { 3. Intrusion/Cognitive Avoidance }\end{array}$ \\
\hline $\begin{array}{l}\text { Larsson et al. } \\
107 \\
\text { DSM not } \\
\text { specified }\end{array}$ & $\begin{array}{l}321 \text { Swedish men and } \\
\text { women involved in the } \\
\text { aftermath of a mass } \\
\text { murder }\end{array}$ & Confirmatory & ${ }_{138}$ Impact of Event Scale & $\begin{array}{l}\text { 1. General Factor } \\
\text { 2. Intrusion } \\
\text { 3. Avoidance } \\
\text { 4. Sleep disturbance }\end{array}$ \\
\hline
\end{tabular}

*Samples are from the United States unless otherwise specified 